\title{
Body morphometrics, swimming diversity and niche in demersal sharks: a comparative case study from the Mediterranean Sea
}

\author{
UMBERTO SCACCO, GABRIELE LA MESA and MARINO VACCHI
}

I.S.P.R.A ex I.C.R.A.M - Via di Casalotti 300, 00166 Rome, Italy. E-mail: umbertoscacco@ hotmail.com

\begin{abstract}
SUMMARY: Seven demersal shark species belonging to six families, obtained from the southern Mediterranean Sea, were selected as representative of different putative swimming modes, inhabited depths and trophic levels. Caudal fin morphometrics (caudal fin span, area and aspect ratio), hepatosomatic index and muscular-skeletal amount per unit length were estimated and compared within and among species by means of both parametric and non-parametric multivariate and univariate statistical procedures. Intra-specific variation was related to size and, for one species only, also to sex. Two inter-specific patterns of variation were observed: the first pattern was interpreted as a swimming ability gradient between slow benthic and more pelagic species, as a function of caudal morphometry and body characteristics; the second pattern is related to the depth the species inhabit and/or their trophic level. These two hypotheses were tested with the current data and literature information, and discussed in the context of shark swimming modes, habit and environment. Based on observed differences in caudal fin morphometrics, liver and muscular masses, this paper is the first to provide a quantitative and comparative dataset for demersal sharks as a group, and attempts to describe sample variability as a function of expected swimming ability and occupied niche (depth inhabited and/or trophic level).
\end{abstract}

Keywords: demersal sharks, swimming ability, tail aspect ratio, hepatosomatic index.

RESUMEN: MORFOMETRÍA CORPORAL, DIVERSIDAD NATATORIA Y NICHO DE LOS TIBURONES DEMERSALES: ESTUDIO COMPARATIVO EN El MAR MEDITERRÁNeO. - Siete especies de tiburones demersales, pertenecientes a 6 familias, capturadas en el sur del mar Mediterráneo, fueron seleccionadas como representantes de diferentes modos de natación, profundidad que suelen habitar y niveles tróficos. La morfometría de la aleta caudal (longitud, área y relación de aspecto), el índice hepatosomático y la relación entre músculo y esqueleto por unidad de longitud fueron determinados y comparados entre los individuos y entre especies a través de procedimientos estadísticos paramétricos y no paramétricos, multivariados y univariados. La variación intra-específica se relacionó con el tamaño y, para una única especie, también con el sexo. Se observaron dos patrones interespecíficos de variación: el primero fue interpretado como un gradiente de la capacidad de natación entre especies bentónicas y las más pelágicas, en función de la morfometría caudal y de las características corporales. El segundo se debió principalmente a la profundidad habitada y / o el nivel trófico. Asociando los datos actuales a la información existente en la literatura, estas dos hipótesis se comprobaron y se examinaron en el contexto del tipo de natación del tiburón y el ambiente marino. A partir de las diferencias observadas en la morfometría de la aleta caudal, el hígado y las masas musculares, este documento ofrece por primera vez una base de datos cuantitativos y comparativos sobre los tiburones demersales, como grupo, intentando describir la variabilidad muestral como una función de la capacidad de natación esperada y de los nichos ocupados (profundidad habitada y/ o nivel trófico).

Palabras clave: tiburones demersales, capacidad natatoria, cociente del aspecto de la cola, índice hepatosomático.

\section{INTRODUCTION}

More than 1200 elasmobranch species are known so far and have colonised a wide range of environ- ments from benthic to open water habitats (Hennemann, 2001; Compagno, 2002). Such enormous evolutionary success is also related to large interspecific variability in body morphology, which determines 
the diversity in swimming mode and niche (feeding and habit) among cartilaginous species (Hennemann, 2001).

Diversity in swimming modes among sharks has been studied by several authors (Breder, 1926; Budker, 1971; Thomson, 1976; Thomson and Simanek, 1977; Lindsey, 1978; Webb and Keyes, 1982; Webb, 1984; Webb and Blake, 1985; Blake, 2004; Wilga and Lauder, 2004b), who have gradually clarified the main factors determining shark swimming.

The position, amplitude and structure of paired (Lighthill, 1970; Webb and Keys, 1982; Webb, 1984) and unpaired (Lingham-Soliar, 2004a, 2004b, 2005; Lingham-Soliar and Plodowski, 2007) fins as well as body shape (Thomson and Simanek, 1977) play an important role in shark swimming and kinematics (Fish and Shannahan, 2000; Wilga and Lauder, 2000; 2001). The motion of the caudal fin is responsible for the largest part of shark propulsion (Wilga and Lauder, 2004b). Some authors (Ferry and Lauder, 1996; Lauder, 2000), thanks to $3 \mathrm{D}$ videography techniques, have demonstrated that the tail of Triakis semifasciata is always at an angle greater than $90^{\circ}$ with the horizontal during horizontal steady swimming. Based on direct measurements of water flow, Wilga and Lauder (2002) demonstrated that the tail of two demersal shark species produce thorus-shape vortex rings; the central ring of such a structure generates an high-velocity vortex jet that is constantly tilted posterodorsally during both horizontal swimming and vertical manoeuvring. This kinematic evidence provides unequivocal support for the classical model of heterocercal tail function in sharks: the tail accelerates water posteroventrally and there is a corresponding reaction force with dorsal (lift) and anterior (thrust) components.

Apart from kinematic patterns, some general morpho-functional interrelationships between the caudal (span and area) and body (liver and muscularskeletal relative masses) morphometrics and shark swimming can be determined.

As first observed in thunnids and euthynnids (Magnuson, 1978), steady swimming generally requires a high caudal span $(S)$ because of the direct proportionality between $S$ and the reduction of drag produced at the tips of the caudal fin while swimming (hence also between $S$ and the tail beat frequency). Webb and Keyes (1982) observed that the tail beat frequency also increases for sharks between elongate and fusiform body shapes, as previously described for non-scombroid fish (Webb,
1978). However, since the thrust produced by a fish is generally proportional to the caudal area $(A)$ (Magnuson, 1978), a high $A$ determines both higher thrust and drag in non-scombroid swimmers (Webb, 1978). As a result, sharks with a larger tail area show more ability in burst swimming with low tail beat frequencies (Webb and Keyes, 1982). The opposite contributes exerted by caudal fin span and area for swimming are mediated by the adimensional caudal fin aspect ratio (expressed by the formula $A_{\mathrm{R}}=S^{2} / A$ ) (Alexander, 1967). The effort a fish needs to move is determined by the ratio between the lift and the drag (Webb and Keys, 1982); this is high when the $A_{\mathrm{R}}$ is also high (Alexander, 1967). The greater the lift-drag ratio is, the less energy required (Sambilay, 1990). Considered a good descriptor of the different fish swimming modes (Kramer, 1960; Aleev, 1963; Lindsey, 1978; Magnuson, 1978), caudal fin $A_{\mathrm{R}}$ varies across a large variety of aquatic vertebrates, from benthic forms, capable of slow and manoeuvrable swimming (low $A_{\mathrm{R}}$ ), to pelagic forms, capable of sustained and prolonged swimming (high $A_{\mathrm{R}}$ ) (Aleev, 1963; Thomson, 1976; Thomson and Simanek, 1977; Webb, 1978; Webb, 1984; Lingham-Soliar, 2004a).

Apart from body and fin shapes, the muscularskeletal apparatus and the size of the liver are the main source of swim power and buoyancy respectively in several shark species. For instance, according to Donley and Shadwick (2003) the red muscle fibres along the entire length of the shark's body are responsible for generating thrust in Triakys semifasciata. Therefore, the proportion of muscular and skeletal masses (which is basically the eviscerated weight) over the shark length can be used to indicate differences in the ability to generate potential swimming power per unit length among the studied species. As they do not have swim bladders, sharks control their buoyancy by swimming actively and/or decreasing their total density by accumulating lipids in their liver (Alexander, 1965, 1968). The shark's liver is the largest organ by weight and ranges from $2 \%$ of the total body weight for medium-small species (Kohler et. al., 1996) to $24 \%$ for the larger ones (Cliff et al. 1989). The ratio between liver and eviscerated mass, namely the hepatosomatic index (HI), may play an important role in passive buoyancy (Bone and Roberts, 1969; Baldridge, 1970, 1972). Although the HI can vary in females of different elasmobranch species after they reach sexual maturity (Koob and Callard, 1999), generally passive buoyancy is not affected due to the transfer of 
lipids from the liver to other tissues (i.e. gonads), as observed in Centroscymnus coelolepis (Corner et. al., 1969; Clarke et. al., 2001), Centroscyllium fabricii (Yano, 1995), Scyliorhinus canicula (Craik, 1978) and Squalus acanthias (Bone and Roberts, 1969). According to Bone and Roberts (1969), such an inter-tissue exchange of lipids maintains a fairly constant percentage weight in seawater for deepwater sharks.

As extensively reviewed and discussed by Higham (2007) and Domenici et al. (2007), locomotion, feeding and ecological constraints cause small but constant stresses to aquatic organisms and act as selection factors for adaptive morphological changes (Gould and Eldredge, 1977; Alberch et al., 1979), even in a relatively short amounts of time (Gould and Eldredge, 1977). However, aquatic organisms adapt to changes that may occur at different rates through phenotypic plasticity and natural selection (Domenici et al., 2007). Recently, scientific debate has been focused on genetic differentiation and/or phenotypic plasticity in elasmobranchs. These phenomena have been hypothesised to account for trophic egg strategy (Perry and Roitberg, 2006), cryptic isolation of the shovelnose guitarfish Rhinobatos productus, Ayres, 1854 (Sandoval-Castillo et al., 2004), and the life-history parameters of the black nose shark Carcharhinus acronotus (Poey, 1860) (Sulikowski et $a l ., 2007)$, all in relation to geographic distribution.

Taking into consideration the suggestions by Higham (2007) and Domenici et al. (2007), interrelationships between body characteristics, swimming ability and occupied niche can also be expected for demersal sharks. The latter represents a group of elasmobranch species with disparate body shapes, distributed from coastal to deep water environments (Compagno, 2002), and that interact with the bottom to different extents (Hennemann, 2001). Data from the literature on sharks (in particular the morphological classification of Thomson and Simanek, 1977) suggest that there is a link between body characteristics, swimming mode and niche in demersal sharks. Thomson and Simanek (1977) divided the shark species into four groups based mainly on the body and caudal fin characteristics. Demersal sharks, generally placed between the anguilliform and the sub-carangiform swimming types (Lindsey, 1978; Wilga and Lauder, 2004b), were split into groups three and four. Group three includes sharks with a fusiform -body shape with a low tail aspect ratio, such as catsharks, hounds and cowsharks. These characteristics indicate adaptation to slow speed and bottom dwelling where enhanced vertical mobility is not as important as cruising efficiency, as the authors pointed out (1977). Group four contains only squaloid species, which are characterised by not having an anal fin, and having a large epicaudal lobe and pectoral fins inserted higher up above the flank than other species.

The Mediterranean elasmobranch fauna includes several demersal shark species (Tortonese, 1956), that have different bathymetrical distributions (Fischer $e t$ al., 1987; Notarbartolo di Sciara and Bianchi, 1998; Massutí and Moranta, 2003; Serena, 2005) and occupy different positions in the food chain (Stergiou and Karpouzi, 2002). Most demersal sharks are targeted by commercial fishing in the Mediterranean (Bertrand et al., 2000), which provides the opportunity to carry out comparative studies. In this work, we selected and compared seven demersal species that represent a significant array of inhabited environments (Fischer et al., 1987; Notarbartolo di Sciara and Bianchi, 1998; Serena, 2005), caudal morphologies, putative swimming modes (Thomson and Simanek, 1977), and feeding habits (Froese and Pauli, 2007). The following species were studied: two scyliorhinids, the deep water benthic blackmouth catshark, Galeus melastomus Rafinesque, 1810 and the coastal benthic small-spotted catshark, Scyliorhinus canicula (Linnaeus, 1758); from the deep-water hexanchid species the sharpnose sevengill shark, Heptranchias perlo (Bonnaterre, 1788); the coastal triakid starry smooth-hound shark, Mustelus asterias Cloquet, 1821; and three squaliformes, the long-nose spur dog, Squalus blainvillei (Risso, 1827), the deep water little gulper, Centrophorus uyato (Rafinesque, 1810) and the kite-fin, Dalatias licha (Bonnaterre, 1788), sharks.

Neither comparative nor quantitative evaluations of differences in caudal morphometrics, hepatosomatic index or muscular-skeletal amount per unit length have ever been assessed in a group of demersal sharks. Such a dataset is central in providing basic elements to investigate diversity among demersal sharks in terms of the interrelationships between body characteristics, swimming ability and ecological factors.

The aims of the present paper are to provide 1) a comparative and quantitative evaluation of differences in caudal fin morphometrics, liver and muscular-skeletal masses among seven selected demersal sharks, and 2) to interpret, based on literature 


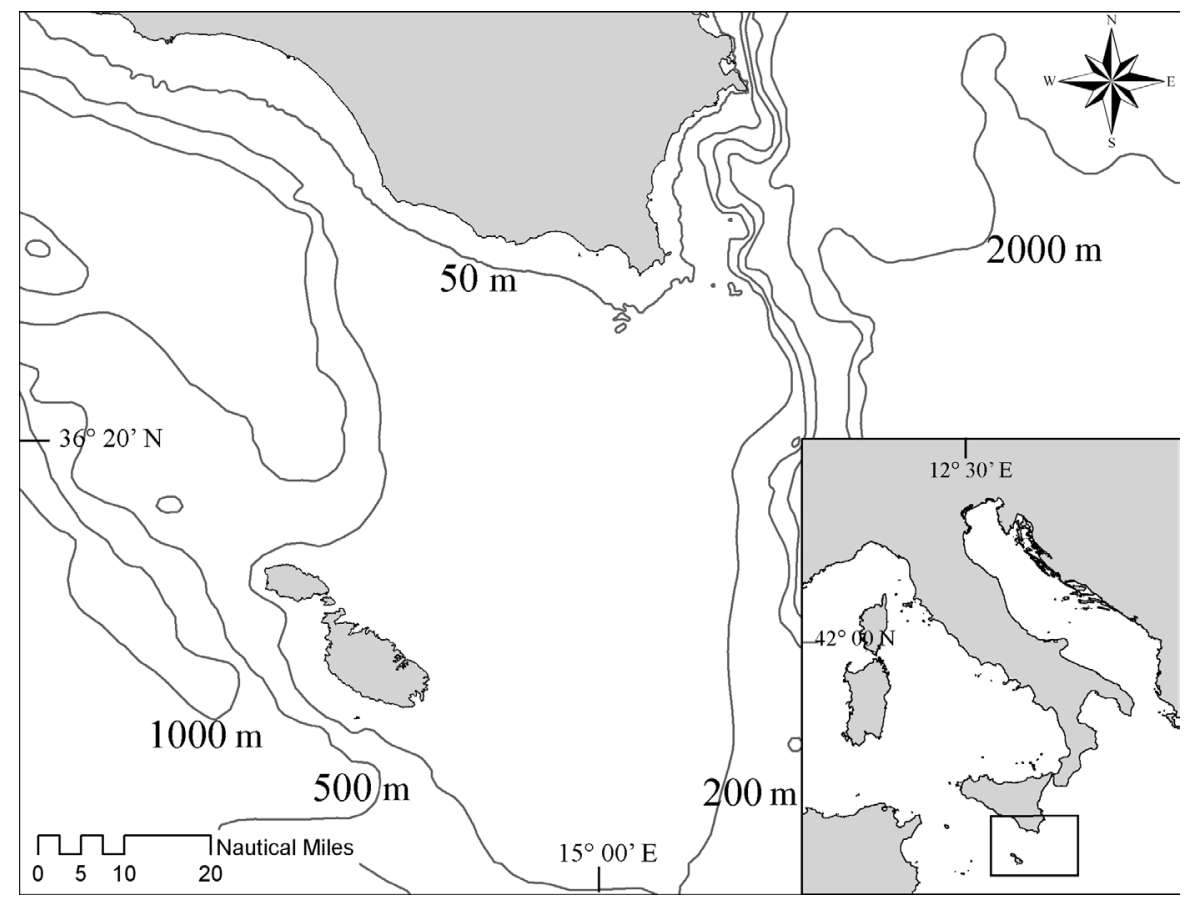

FIG. 1. - Geographic location of the shark sampling area.

data, the observed patterns of variation in the context of shark swimming, feeding and environmental characteristics.

\section{MATERIALS AND METHODS}

\section{Sample collection and measurements}

All samples were collected during a three-year survey of landings (2000-2002) at Portopalo di Capopassero (SE Sicily) (Fig. 1). All specimens came from commercial otter trawlers fishing in coastal and deep grounds (100-800 m) in the Malta Channel. The species studied were Galeus melastomus (31 0 and 30 \%), Scyliorhinus canicula ( $80^{\star}$ and 9q), Heptranchias perlo (8 $80^{\star}$ and $6 \%$ ), Mustelus asterias (5 $0^{\star}$ and $2 \%$ ), Squalus blainvillei (78 $0^{\star}$ and $127 \%$ ), Centrophorus uyato (8 0 and $3 q$ ) and Dalatias licha (11 $0^{\star}$ and $53 \%$ ). Their acronyms (" $g$ ", "s", " $h$ ", " $m$ ", "sb" (sbf: females; sbm: males), " $c$ " and " $d$ " respectively) were used in the methods and results (text and graphs) sections.

Each specimen was sexed, measured (total length and pre-caudal length, $T_{\mathrm{L}}$ and $P_{\mathrm{L}}$ respectively) to the nearest $\mathrm{mm}$ and weighted (liver, gonad, eviscerated and total masses, $L_{\mathrm{M}}, G_{\mathrm{M}}, E_{\mathrm{M}}$ and $T_{\mathrm{M}}$ respectively) to the nearest $0.01 \mathrm{~g}$. To measure tail span $(S)$ and caudal fin area $(A)$, each specimen was laid on a smooth, mono-coloured surface (a rectangular foam camping pad) and the caudal fin was arranged so that three imaginary lines (one passing through the lower insertion of the caudal fin into the caudal peduncle and the other two through the lower and upper lobe tips of the caudal fin) were settled perpendicularly to the shark horizontal axis (Fig. 2). Using a digital camera, pictures of the caudal region were taken perpendicularly to its surface. Measurements of $S$ and $A$ (Fig. 2) were subsequently obtained by a software for image analysis (IMAGE-PROPLUS). System calibration was performed using a $10 \mathrm{~cm}$ portion of a ruler next to each photographed specimen.

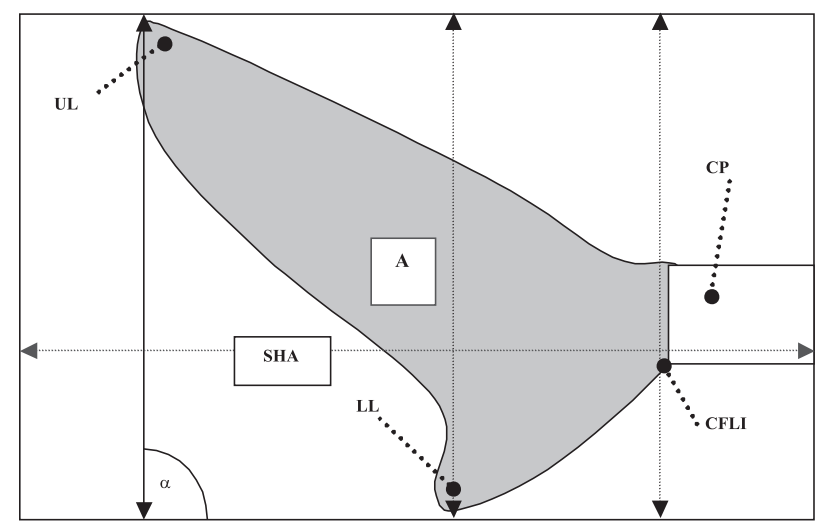

FIG. 2. - Schematic representation of the sagittal section of the heterocercal caudal fin and morphometric measurements of the caudal fin span $(S)$ and caudal fin area $(A$, in grey zone) digitally collected $\alpha=90$ : angle between $S$ and shark horizontal axis. SHA: shark horizontal axis; CP: caudal peduncle; CFLI: caudal fin lower insertion; LL: lower lobe; UL: upper lobe. 


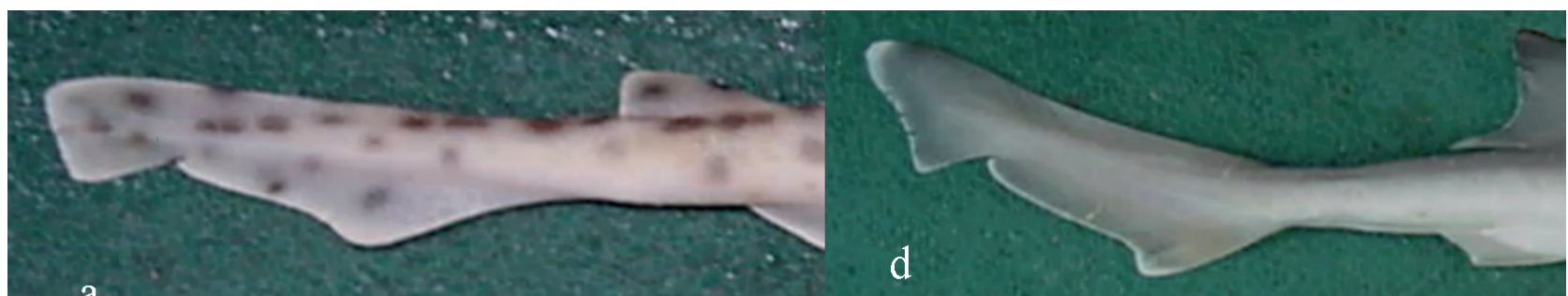

a
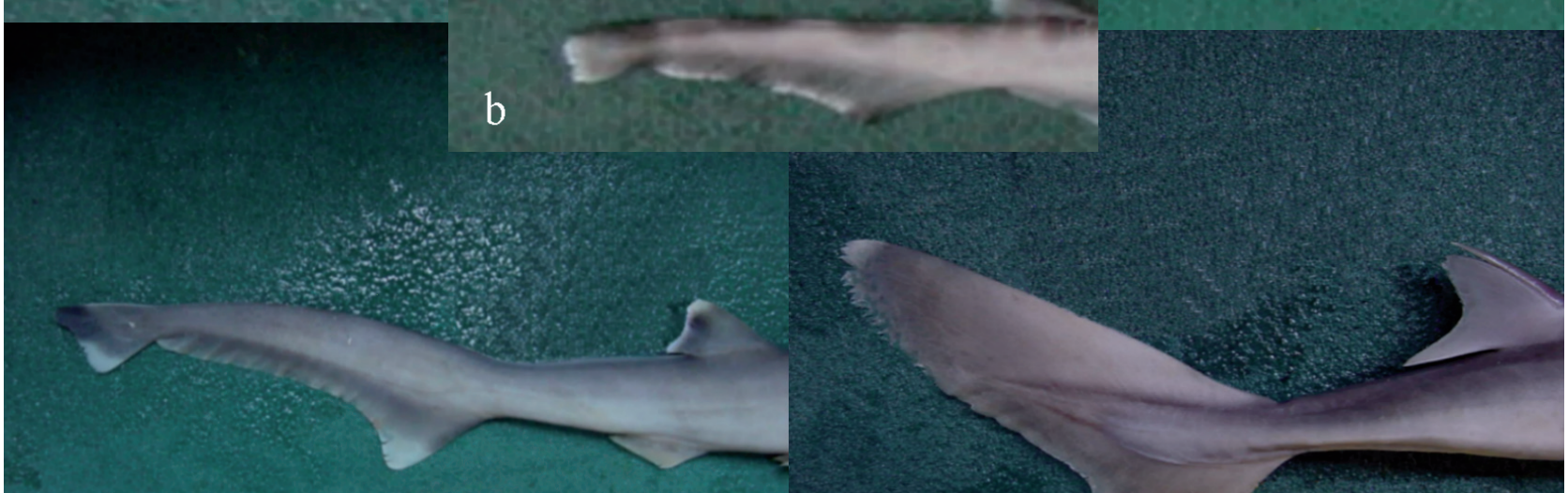

C
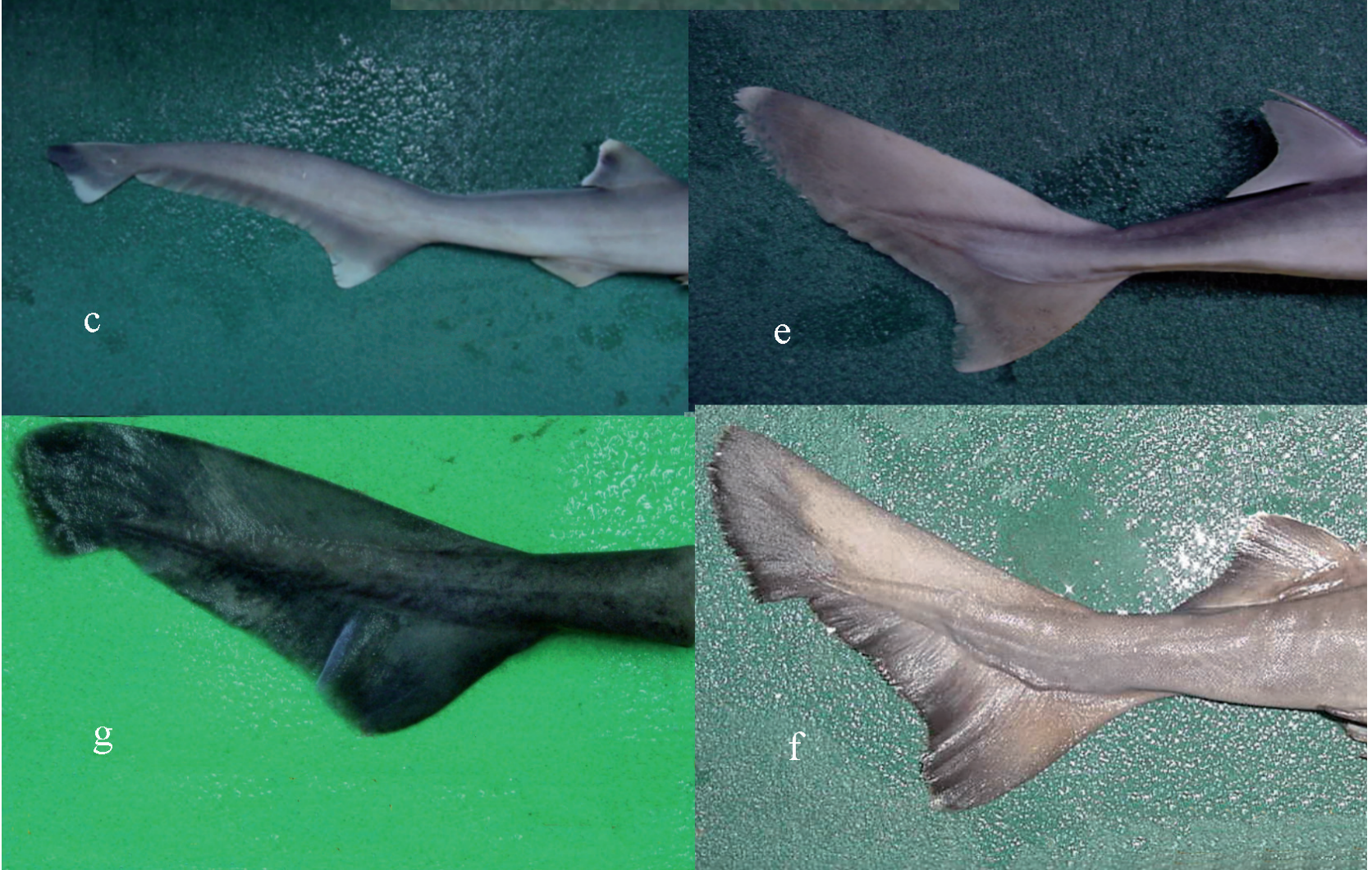

FIG. 3. - Digital photos of heterocercal tail fins of the seven investigated demersal sharks. (a): Scyliorhinus canicula, ô, $245 \mathrm{~mm}$ TL; (b): Galeus melastomus, ô, $280 \mathrm{~mm}$ TL; (c): Heptranchias perlo, ô, $600 \mathrm{~mm}$ TL; (d): Mustelus asterias, ㅇ, $480 \mathrm{~mm}$ TL; (e): Squalus blainvillei,

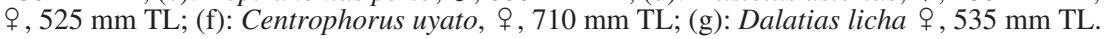

\section{Description of caudal shape}

In the two catsharks studied, the tail shape was rather low and long with the upper lobe delimited by a sub-terminal notch and the lower lobe not very prominent (Fig. 3a, b). The caudal fin shape of $H$. perlo (Fig. 3c), although similar to that of a catshark, differs in having proportionally more developed upper and lower caudal lobes. Conversely, M. asterias has a higher and shorter tail with a convoluted margin and a large and protruding upper lobe with a deep sub-terminal notch (Fig. 3d). S. blainvillei has a straight margin with rounded lobes, the upper one without a notch (Fig. 3e). In both $C$. uyato and $D$. licha, the sub-terminal notch is well developed and the straightness of the posterior margin is intermediate between that of M. asterias and that of S. blainvillei. Nevertheless, both lobes are more acute and developed in C. uyato than in D. licha (Fig. 3f, g).

\section{Data analysis}

Measurements of $S$ and $A$ were performed four times for each specimen. The reliability of the meas- 
uring method was ascertained by computing intraclass correlation coefficients for individual repeated measures of $A$ and $S$ separately within each species. Whenever necessary, data were transformed and tested again. Mean values for $S$ and $A$ (over four replicates) were used to calculate the individual aspect ratio, defined as $A_{\mathrm{R}}=S^{2} / A$. Individual values of $L_{\mathrm{M}}$ were used to calculate the hepatosomatic index $\left(H_{\mathrm{I}}\right)$ following the formula $H_{\mathrm{I}}=\left(L_{\mathrm{M}} / E_{\mathrm{M}}\right) 100$. For females, gonad mass was added to liver mass $\left(H_{\mathrm{I}}=\right.$ $\left.\left.\left(L_{\mathrm{M}}+G_{\mathrm{M}}\right) / E_{\mathrm{M}}\right) 100\right)$ to compensate the inter-tissue transfer effect of lipids (see Introduction).

In order to perform a parametric statistical treatment of data, normality and homoscedasticity of $S$, $A, A_{\mathrm{R}}, H_{\mathrm{I}}$ and $E_{\mathrm{M}}$ were tested using the KomolgorovSmirnov and Bartlett tests respectively. Whenever necessary, data were transformed and tested again. These parametric assumptions were verified in $g$, $s$, $s b$ and $d$ only.

Therefore, an ANCOVA with fish size as the covariate was used to test for differences in all the studied variables $\left(S, A, A_{\mathrm{R}}, H_{\mathrm{I}}\right.$ and $\left.E_{\mathrm{M}}\right)$ both between sexes and among species. When differences between sexes were not found, differences among species were analysed with pooled data. Multiple comparison among slopes were performed by an STP test (Sokal and Rohlf, 1995). Linear regressions for the morphometric variables $S, A$ and $A_{\mathrm{R}}$ were constructed using $P_{\mathrm{L}}$ as the independent variable. Due to the linear model applied, square root transformation was needed for $A$. In the case of $A_{\mathrm{R}}$, natural logarithmic transformation of $P_{\mathrm{L}}$ was needed because of different variation ranges of the regressed variables (Sokal and Rohlf, 1995). $H_{\mathrm{I}}$ and $E_{\mathrm{M}}$ were regressed on $T_{\mathrm{L}}$. The $E_{\mathrm{M}}-T_{\mathrm{L}}$ relationship was obtained on log-log transformed data.

To compensate the significant effect of fish size detected for all the studied variables by ANCOVA, $A, S$ and $E_{\mathrm{M}}$ were standardised with body size as follows: $A^{\prime}=\left(A /\left(P_{\mathrm{L}}\right)^{2}\right) 100, S^{\prime}=\left(S / P_{\mathrm{L}}\right) 100$ and $E_{\mathrm{M}}{ }^{\prime}=$ $E_{\mathrm{M}} / P_{\mathrm{L}} A_{\mathrm{R}}$ and $H_{\mathrm{I}}$ did not need standardisation as they are individual ratios. In order to obtain a reliable comparison among the seven species, both univariate and multivariate non-parametric analyses of variance were applied to this new dataset.

As a first step, sexual differences within species for $A_{\mathrm{R}}, A^{\prime}, S^{\prime}, E_{\mathrm{M}}$ ' and $H_{\mathrm{I}}$ were evaluated using the Mann-Whitney U Test. When no sexual difference was detected, inter-specific comparison was performed on pooled data using PERMANOVA (for the entire variable dataset, $H_{0}$ : compared groups do not differ from each other in relation to all the analysed variables) and a Kruskal-Wallis ANOVA (for each variable). A post-hoc procedure was carried out with a Mann-Whitney U Test, adjusted with Bonferroni's correction for multiple comparisons (28) (Siegel and Castellan, 1992; Underwood, 1997). The patterns of similarity and variation among species in relation to all variables were studied by means of two ordination techniques. Cluster analysis (average linkage algorithm, UPGMA method; Krebs, 1989) was run on variable median values, using Euclidean distances as similarity measures among species.

Based on correlations, principal component analysis (PCA) was run on individual values of $S^{\prime}, A^{\prime}$, $H_{\mathrm{I}}$ and $E_{\mathrm{M}}$ ', chosen as active variables; $A_{\mathrm{R}}$, trophic level (Tr lev) and depth inhabited (In dep) were used as supplementary variables (Graffelman and AlujaBanet, 2003). The graphic representation of the PCA results was based on a biplot display (Gabriel, 1971; Gabriel, 1982; Gabriel and Odoroff, 1990; Gower and Hand, 1996). Median and mean values, obtained from literature data, were used as reliable measures of In dep and Tr lev respectively (extrapolated for unfished populations) for each species in the Mediterranean. These variables were simultaneously regressed over median values of species' coordinates along a vertical component by means of multiple regression analysis in order to find the better predictor for the vertical gradient. The horizontal gradient was interpreted by simple regression analysis of $A_{\mathrm{R}}$ individual fish values over individual fish coordinates along the horizontal component.

All statistical analyses were performed using STATISTICA 6.0 (Stasoft), PRIMER 6.0 and PERMANOVA + (Plymouth Marine Laboratory, UK; Clarke and Warwick, 2001).

\section{RESULTS}

\section{Literature data on feeding behaviour and depth distribution}

The coastal benthic shark $S$. canicula inhabits continental shelves and uppermost slopes (Fischer et al., 1987; Notarbartolo di Sciara and Bianchi, 1998; Serena, 2005). The food preferred by this species consists of several types of benthic and bathy-demersal prey (Macpherson, 1979; Gibson and Ezzi, 1987; Carrassón et al., 1992; Cortès, 1999). The trophic level of this catshark is around 3.62 (Ellis et al., 
1996). The deep water benthic shark G. melastomus is found on the outer continental shelves and upper slopes (Fischer et al., 1987; Notarbartolo di Sciara and Bianchi, 1998; Serena, 2005). Though it shares several food items with S. canicula (Macpherson, 1979; Gibson and Ezzi, 1987; Carrassón et al., 1992; Cortès, 1999), the diet of G. melastomus is characterised by a massive presence of myctophids and paralaepidids (Notolepis and Paralepis sp.), mostly in adult individuals (Belluscio et al., 2000; Olaso et al., 2004). The trophic level of this species has been estimated at around 4.09 (Carasson et al., 1992). M. asterias is a common inshore and offshore shark found on the continental and insular shelves from the intertidal area down to at least $500 \mathrm{~m}$ (Fischer et al., 1987; Notarbartolo di Sciara and Bianchi, 1998; Serena, 2005). It is a zoo-benthic feeder, preying especially on crustaceans such as crabs, hermit crabs, lobsters and slipper lobsters (Ellis et al., 1996), using its highly specialised teeth, typical of crushingtype dentition (Hennemann, 2001). The trophic level for the unfished population of this shark has been estimated at 3.64 (Cortès, 1999). The bathydemersal shark $H$. perlo lives in deep water, preferentially on the outer continental and insular shelves and upper slopes, but also inshore (Fischer et al., 1987; Notarbartolo di Sciara and Bianchi, 1998; Serena, 2005). It hunts for faster prey, such as small sharks, rays, bony fish, squid and cuttlefish, but also feeds on shrimps, crabs and lobsters, and has a trophic level of about 4.06 (Cortés, 1999). The demersal shark $S$. blainvillei is found on the continental shelves and upper slopes (Fischer et al., 1987; Notarbartolo di Sciara and Bianchi, 1998; Serena, 2005). Its diet is based on both nektonic organisms, such as denticids, mackerel and percichthyids, and benthic organisms, such as crabs, lobsters, and octopi. It has a trophic level of around 3.87 (Cortés, 1999). The common deepwater dogfish $C$. uyato lives on the outer continental shelves and upper slope (Fischer et al., 1987; Notarbartolo di Sciara and Bianchi, 1998; Serena, 2005). It is a very active feeder, and usually hunts for quick bony fish and squid (Macpherson and Roel, 1987). It has a trophic level of about 4.50 (Compagno, 1984). D. licha is found on the outer continental and insular shelves and slopes (Fischer et al., 1987; Notarbartolo di Sciara and Bianchi, 1998; Serena, 2005). Cortés (1999) found a large proportion (80\%) of fast nektonic preys in the stomachs of this species, such as the deepwater bony fish Trachyrhynchus trachyrhynchus and Notoscopelus elongatus (Macpherson, 1979), other sharks and cephalopods (squids and cuttlefish) (Compagno et al., 1989). According to Compagno et al., (1989), benthic items (skates, shrimps and prawns) are also present. The trophic level of the deep water shark $D$. licha was estimated at around 4.05 (Cortés, 1999).

Literature data on depth distribution (In dep) and trophic level ( $\operatorname{Tr} l e v)$ of the studied species in the Mediterranean are summarised in Table 1.

\section{Size and sex-related differences}

High intra-class correlations $\left(\mathrm{r}_{\text {intra }} \cong 1, P<0.05\right)$ demonstrated the reliability of the measurement method for $A$ and $S$.

For $g, s, s b f$, sbm and $d$, which met the assumptions of a parametric analysis, all variables were positively size-related with the exception of $H_{\mathrm{I}}$ for catsharks ( $g$ and $s$ ), as their linear $H_{\mathrm{I}}-T_{\mathrm{L}}$ relationships were not significant (Table 2). Comparing the sexes of the four studied species, $g, s$ and $d$ did not show

TABLE 1. - Upper, median and lower depth limits (In dep) and mean trophic level (Tr lev) for Galeus melastomus (g), Sciliorhinus canicula $(s)$, Mustelus asterias (m), Heptranchias perlo ( $h$ ), Squalus blainvillei (sb), Dalatias licha (d) and Centrophorus uyato (c). Mediterranean depth limits for studied species are obtained from Fischer et al., 1987 (a), Notarbartolo di Sciara and Bianchi, 1998 (b) and Serena, 2005 (c). The median was extrapolated in the present paper $(\mathrm{d})$. Trophic levels with standard error (S. E.) for studied species were obtained from data available on www.fishbase.org, version (10/07) (data extrapolated for the unfished population of the original samples of Carasson et al. 1992 (e), Ellis et al. 1996 (f), Cortès, 1999 (g) and Compagno, 1984 (i).

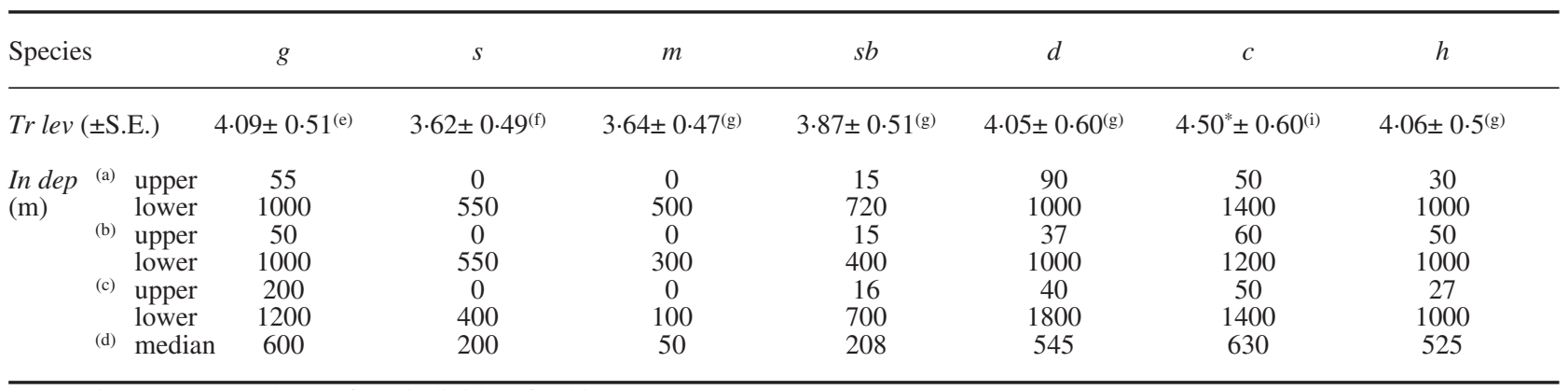

* Trophic level was evaluated from individual food items 
TABLE 2. - Results of the linear regression analysis used to study the size-related variation of caudal fin span $(S)$, transformed caudal area $\left(A^{0.5}\right)$, aspect ratio $\left(A_{\mathrm{R}}\right)$ hepatosomatic index $\left(H_{\mathrm{I}}\right)$ and eviscerated mass $\left(E_{\mathrm{M}}\right)$ in Sciliorhinus canicula $(s)$, Galeus melastomus $(g)$, Squalus blainvillei $\left(s b, s f\right.$ : females; $s m$ : males) and Dalatias licha $(d)$. Independent variables in each analysis are shown in parentheses: $P_{\mathrm{I}}:$ pre-caudal length; Ln $\left(P_{\mathrm{L}}\right)$ : natural logarithmic transformed pre-caudal length; $T_{\mathrm{L}}$ : total length; $\log \left(T_{\mathrm{L}}\right)$ : $\log$ arithmic transformed total length.

\begin{tabular}{|c|c|c|c|c|c|c|}
\hline Variables & Species & Slope $\pm($ S.E. $)$ & Intercept ( \pm S.E.) & $\mathrm{R}^{2}$ & d.f. (F Test) & p-level \\
\hline $\mathrm{S}\left(P_{L}\right)$ & $\begin{array}{c}s \\
g \\
s b \\
d\end{array}$ & $\begin{array}{c}0 \cdot 084 \pm 0 \cdot 0036 \\
0 \cdot 13 \pm 0 \cdot 0007 \\
0 \cdot 21 \pm 0 \cdot 0018 \\
0 \cdot 25 \pm 0 \cdot 0101\end{array}$ & $\begin{array}{c}3.38 \pm 1.04 \\
(-3.59) \pm 0.11 \\
(-7.70) \pm 0.72 \\
(-19.49) \pm 6.74\end{array}$ & $\begin{array}{l}0 \cdot 97 \\
0 \cdot 99 \\
0 \cdot 90 \\
0 \cdot 90\end{array}$ & $\begin{array}{c}1 ; 15 \\
1 ; 59 \\
1 ; 203 \\
1 ; 62\end{array}$ & $\begin{array}{l}* * * \\
* * * \\
* * * \\
* * *\end{array}$ \\
\hline $\mathrm{A}_{\mathrm{R}}\left(\operatorname{Ln}\left(P_{L}\right)\right)$ & $\begin{array}{c}s \\
g \\
s b \\
d\end{array}$ & $\begin{array}{l}0 \cdot 17 \pm 0 \cdot 0597 \\
0 \cdot 24 \pm 0.0084 \\
0.75 \pm 0.0647 \\
0.78 \pm 0.0950\end{array}$ & $\begin{array}{l}(-0.42) \pm 0.33 \\
(-0.90) \pm 0.04 \\
(-2.73) \pm 0.38 \\
(-3.34) \pm 0.61\end{array}$ & $\begin{array}{l}0 \cdot 36 \\
0 \cdot 93 \\
0 \cdot 39 \\
0 \cdot 52\end{array}$ & $\begin{array}{c}1 ; 15 \\
1 ; 59 \\
1 ; 203 \\
1 ; 62\end{array}$ & $\begin{array}{l}* * \\
* * * \\
* * * \\
* * *\end{array}$ \\
\hline$A^{0.5}\left(P_{L}\right)$ & $\begin{array}{c}s \\
g \\
s b \\
d\end{array}$ & $\begin{array}{c}0 \cdot 082 \pm 0 \cdot 0120 \\
0 \cdot 16 \pm 0 \cdot 0033 \\
0 \cdot 13 \pm 0 \cdot 0030 \\
0 \cdot 16 \pm 0 \cdot 0038\end{array}$ & $\begin{array}{c}12 \cdot 20 \pm 3 \cdot 40 \\
4 \cdot 42 \pm 0 \cdot 51 \\
7 \cdot 50 \pm 1 \cdot 18 \\
4 \cdot 82 \pm 2 \cdot 58\end{array}$ & $\begin{array}{l}0 \cdot 75 \\
0 \cdot 97 \\
0 \cdot 90 \\
0 \cdot 96\end{array}$ & $\begin{array}{c}1 ; 15 \\
1 ; 59 \\
1 ; 203 \\
1 ; 62\end{array}$ & $\begin{array}{l}* * * \\
* * * \\
* * * \\
* * *\end{array}$ \\
\hline$H_{\mathrm{I}}\left(T_{\mathrm{L}}\right)$ & $\begin{array}{c}s \\
g \\
s b f \\
s b m \\
d\end{array}$ & $\begin{array}{c}0 \cdot 0243 \pm 0 \cdot 013 \\
(-0 \cdot 0009) \pm 0 \cdot 001 \\
0 \cdot 0420 \pm 0 \cdot 005 \\
0 \cdot 0150 \pm 0 \cdot 004 \\
0 \cdot 0250 \pm 0 \cdot 004\end{array}$ & $\begin{array}{c}(-3.02) \pm 4.63 \\
4.58 \pm 0.30 \\
(-9.68) \pm 2.89 \\
0.67 \pm 2.21 \\
17.82 \pm 3.50\end{array}$ & $\begin{array}{c}0 \cdot 21 \\
0 \cdot 007 \\
0 \cdot 50 \\
0 \cdot 10 \\
0 \cdot 39\end{array}$ & $\begin{array}{l}1 ; 12 \\
1 ; 59 \\
1 ; 54 \\
1 ; 97 \\
1 ; 57\end{array}$ & $\begin{array}{c}\mathrm{ns} \\
\mathrm{ns} \\
* * * \\
* * \\
* * *\end{array}$ \\
\hline $\log \left(E_{M}\right)\left(\log \left(T_{L}\right)\right)$ & $\begin{array}{c}s \\
g \\
s b \\
d\end{array}$ & $\begin{array}{l}3 \cdot 38 \pm 0 \cdot 13 \\
3 \cdot 07 \pm 0 \cdot 04 \\
3 \cdot 05 \pm 0 \cdot 04 \\
3 \cdot 14 \pm 0 \cdot 07\end{array}$ & $\begin{array}{c}(-6.59) \pm 0.33 \\
(-5.75) \pm 0.09 \\
(-5.55) \pm 0.12 \\
(-5.93) \pm 0.20\end{array}$ & $\begin{array}{l}0.98 \\
0.99 \\
0.96 \\
0.97\end{array}$ & $\begin{array}{c}1 ; 15 \\
1 ; 59 \\
1 ; 203 \\
1 ; 62\end{array}$ & $\begin{array}{l}* * * \\
* * * \\
* * * \\
* * *\end{array}$ \\
\hline
\end{tabular}

*** $\mathrm{p}<0.001 ; * * \mathrm{p}<0.01 ; \mathrm{ns}$ : not significant

TABLE 3. - Results of the comparison of regression slopes of caudal fin span $(S)$, transformed caudal area $\left(A^{0.5}\right)$, aspect ratio $\left(A_{\mathrm{R}}\right)$, hepatosomatic index $\left(H_{\mathrm{I}}\right)$ and $\log$-transformed eviscerated mass ( $\left.\log E_{\mathrm{M}}\right)$ among Sciliorhinus canicula $(\mathrm{s})$, Galeus melastomus ( $\left.\mathrm{g}\right)$, Squalus blainvillei (sb, $s f$ : females; $s m$ : males) and Dalatias licha $(d)$. Variables used as covariates in each analysis are shown in parentheses: $P_{\mathrm{L}}:$ pre-caudal length; Ln $\left(P_{\mathrm{L}}\right)$ : natural logarithmic transformed pre-caudal length; $T_{\mathrm{L}}$ : total length. Underlined species are not significantly different.

\begin{tabular}{|c|c|c|c|c|c|c|c|}
\hline \multirow{3}{*}{$\begin{array}{l}\text { Variable } \\
S\left(P_{L}\right)\end{array}$} & \multicolumn{2}{|c|}{ Test for Homogeneity of Slope } & \multicolumn{5}{|c|}{ Simultaneous Test Procedure } \\
\hline & d.f. (F Test) & p-level & & Speci & ariso & & p-level \\
\hline & $3 ; 339$ & $* * *$ & $s$ & $g$ & $s b$ & $d$ & $* * *$ \\
\hline$A^{0.5}\left(P_{L}\right)$ & $3 ; 339$ & $* * *$ & $s$ & $s b$ & $g$ & $d$ & $* * *$ \\
\hline$A_{R}\left(\operatorname{Ln}\left(P_{L}\right)\right)$ & $3 ; 339$ & $* * *$ & $s$ & $g$ & $s b$ & $d$ & $* * *$ \\
\hline$H_{I}\left(T_{L}\right)$ & $2 ; 208$ & $* *$ & $s b m$ & $d$ & $s b f$ & & $*$ \\
\hline $\log \left(E_{\mathrm{M}}\right)(\log (T L))$ & $3 ; 339$ & $*$ & $s b$ & $g$ & $d$ & $S$ & $*$ \\
\hline
\end{tabular}

*** $\mathrm{p}<0.001 ; * * \mathrm{p}<0.01 ; * \mathrm{p}<0.05$

differences in the aforementioned relationships while $s b$ showed a higher $H_{\mathrm{I}}-T_{\mathrm{L}}$ slope for females (ANCOVA, test for homogeneity of slope, d.f 1 and $151, P<0 \cdot 001)$.

Significant differences were found in the slope comparison among species for all the regressed variables (Table 3). The lowest and the highest slopes for the $A^{0.5} P_{\mathrm{L}}$ relationship were observed for $s$ and $d$ respectively, whereas no difference was found between $s b$ and $g$ or between $g$ and $d$ (Fig. 4). The slopes for the $S-P_{\mathrm{L}}$ relationship were similar in the catsharks $g$ and $s$, and lower compared to the squaloids $s b$ and $d$. The $A_{\mathrm{R}}-\mathrm{Ln}\left(P_{\mathrm{L}}\right)$ relationship showed similar slopes for catsharks $g$ and $s$, and were lower compared to the squaloids $s b$ and $d$. Comparing $H_{\mathrm{I}}-T_{\mathrm{L}}$ relationships, $s b f$ exhibited a higher slope value than those of $s b m$ and $d$, which were similar. Comparing Log $\left(E_{\mathrm{M}}\right)-\log \left(T_{\mathrm{L}}\right)$ relationships, the catshark $s$ and the squaloid $d$ showed higher slope values compared to the catshark $g$ and the squaloid $s b$ (sbf plus $s b m$ ). 


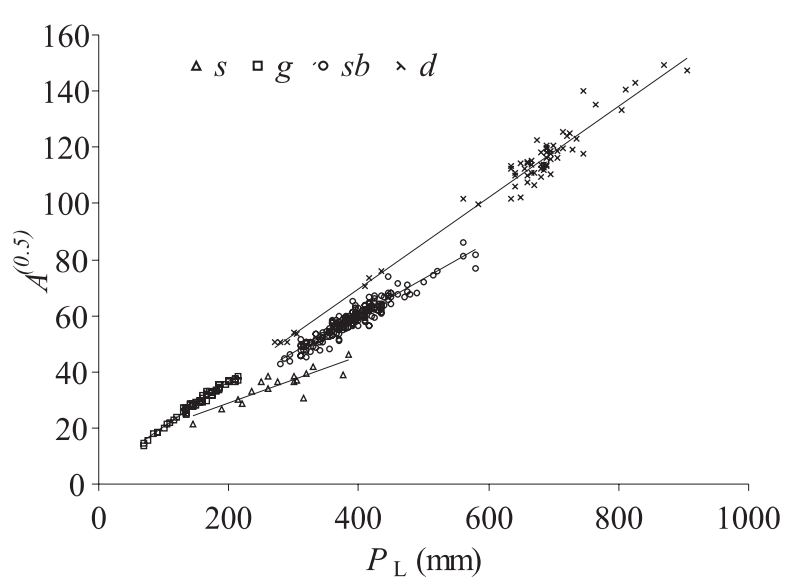

FIG. 4 - Relationships between square root transformed caudal fin area $\left(A^{0.5}\right)$ and precaudal length $\left(P_{\mathrm{L}}\right)$ in Galeus melastomus ( $g$, open squares), Scyliorhinus canicula ( $s$, open triangles), Squalus blainvillei ( $s b$, open circles) and Dalatias licha (d, asterisks).

TABLE 4 - Results of the PERMANOVA based on caudal fin aspect ratio, body size-standardised caudal fin area and span, hepatosomatic index and muscular-skeletal amount per unit length of Galeus melastomus, Scyliorhinus canicula, Mustelus asterias, Heptranchias perlo, Centrophorus uyato, Squalus blainvillei and Dalatias licha.

\begin{tabular}{lcccccc}
\hline Source & df & SS & MS & Pseudo-F & $\begin{array}{c}\mathrm{P} \\
\text { (perm) }\end{array}$ & $\begin{array}{c}\text { Unique } \\
\text { perms }\end{array}$ \\
\hline $\begin{array}{lccccc}\text { Species } \\
\text { Residuals } \\
\text { Total }\end{array}$ & $\begin{array}{l}771 \\
378\end{array}$ & $\begin{array}{c}95763 \\
1.101 * 10^{5}\end{array}$ & $\begin{array}{l}13680 \\
1.104\end{array}$ & $354 \cdot 02$ & 0.001 & 997 \\
\hline
\end{tabular}

Sex-related differences in intra-specific nonparametric comparisons were found only for $s b$, for all variables except $E_{\mathrm{M}}$ '. Median values of $S$, $A^{\prime}$ and $H_{\mathrm{I}}$ were all significantly lower in $s b m$ than in $\operatorname{sbf}$ (Mann Whitney U test: $S^{\prime}:{ }^{\prime} 127$, $q 78$, $P<0.05 ; A^{\prime}:$ ô 127 , o $78, P<0 \cdot 001 ; H_{\mathrm{I}}:$ o 99 , ㅇ $56, P<0 \cdot 001)$, whereas the opposite was observed for $A_{\mathrm{R}}$ (Mann Whitney $\mathrm{U}$ test: $A_{\mathrm{R}}$ : ơ 127, o 78 , $P<0 \cdot 05)$.

\section{Multivariate and univariate results}

The results from the PERMANOVA analysis and Kruskal-Wallis ANOVA indicated that all the studied species differed significantly from each other in relation to all the variables analysed (Table 4) and to each single variable (Table 6) respectively.

In the PERMANOVA pair-wise comparisons (Table 5), the Euclidean distance within groups (measure of data dispersion within species) varied between the lowest value in $g$ and the highest one observed in $d$, whereas the Euclidean distances between groups (the measure of dissimilarity between species) varied between the lowest value in the $g$-s pair wise comparison and the highest one observed in the $g-c$ comparison.

Median values of proportional caudal fin area $\left(A^{\prime}\right)$ increased significantly (Fig. 5a; Table 6) from $m$ to $g$ (from $1.66 \%$ to $3.71 \%$ respectively), although $m$ did not differ from $s$, and both $s b m$ and $s b f$ did not differ from $c$ (Table 6). Median values of $S$ ' and $A_{\mathrm{R}}$ (Fig. 5b and 5c, respectively) increased significantly (Table 6) from $s$ to $d$ (9\% to $22 \%$ circa) and from $g$ to $c(0 \cdot 32$ to $2 \cdot 0)$ respectively. Post-hoc multiple comparisons (Table 6) indicated that all the squaloid sharks ( $s b m, s b f, d$ and $c$ ) had similar values for $A_{\mathrm{R}}$, while for S', $d$ and $c$, as well as $h, s b m$ and $s b f$, had similar results. Median values of the hepatosomatic index $\left(H_{\mathrm{I}}\right)$ were very high for $c$ and $d(38 \%$ circa), whereas the remaining species' values ranged between $4 \%$ and $10 \%$ circa (Fig. 5d). No differences were found between $g$ and $s, d$ and $c$, or among all the remaining species (Table 6). Finally, median values of muscular-skeletal amount per unit length $\left(E_{\mathrm{M}}{ }^{\prime}\right)$ increased significantly (Table 6) between $g$ and $c$ (Fig. 5e), ranging from 2 to $42 \mathrm{~g} / \mathrm{cm}$ circa respectively. Post-hoc multiple comparison showed that $s b$ and $h$ were not different (Table 6).

TABLE 5. - Results of PERMANOVA pairwise post-hoc comparison among species ( $g$ : Galeus melastomus, s: Scyliorhinus canicula, m: Mustelus asterias, $h$ : Heptranchias perlo, $c$ : Centrophorus uyato, sbf: Squalus blainvillei female, sbm: Squalus blainvillei male, $d$ : Dalatias licha). Euclidean distances within groups (dwg), between groups (dbg) and $P$-level of significance $(* * *<0 \cdot 001, * *<0 \cdot 01)$ are reported.

\begin{tabular}{|c|c|c|c|c|c|c|c|c|c|c|c|c|c|c|c|c|c|c|}
\hline Specie & $\begin{array}{l}\text { es } \\
\text { dwg }\end{array}$ & $\begin{array}{c}g \\
\mathrm{dbg}\end{array}$ & $\mathrm{P}$ & $\begin{array}{c}s \\
\text { dwg dbg }\end{array}$ & P & dwg & $\begin{array}{c}m \\
\mathrm{dbg}\end{array}$ & P & $\begin{array}{c}h \\
\text { dwg dbg }\end{array}$ & P & $\begin{array}{c}c \\
\text { dwg dbg }\end{array}$ & $P$ & $\begin{array}{r}s b f \\
\text { dwg dbg }\end{array}$ & $\mathrm{P}$ & dwg & $\begin{array}{l}s b m \\
\mathrm{dbg}\end{array}$ & $P$ & $\begin{array}{c}d \\
\text { dwg }\end{array}$ \\
\hline$g$ & 1.6 & & & & & & & & & & & & & & & & & \\
\hline$s$ & & 4.5 & $* * *$ & 4.4 & & & & & & & & & & & & & & \\
\hline$m$ & & 7.9 & $* * *$ & $6 \cdot 7$ & $* * *$ & 1.9 & & & & & & & & & & & & \\
\hline$h$ & & $17 \cdot 4$ & $* * *$ & $16 \cdot 6$ & $* * *$ & & $11.7 *$ & $* * *$ & $8 \cdot 1$ & & & & & & & & & \\
\hline$c$ & & $50 \cdot 6$ & $* * *$ & $48 \cdot 6$ & $* * *$ & & $43.2=$ & $* * *$ & 37.9 & $* * *$ & $12 \cdot 3$ & & & & & & & \\
\hline$s b f$ & & $16 \cdot 1$ & $* * *$ & 15.5 & $* * *$ & & $10 \cdot 1$ & $* * *$ & 9.4 & $* *$ & 37.5 & $* * *$ & $7 \cdot 3$ & & & & & \\
\hline$s b m$ & & 13.9 & $* * *$ & 13.4 & $* * *$ & & 8.2 & $* * *$ & $7 \cdot 5$ & $* * *$ & $40 \cdot 1$ & $* * *$ & $6 \cdot 1$ & $* * *$ & 3.4 & & & \\
\hline$d$ & & $45 \cdot 4$ & $* * *$ & 43.7 & $* * *$ & & 38.5 & $* * *$ & $35 \cdot 6$ & $* * *$ & $15 \cdot 8$ & $* *$ & $33 \cdot 4$ & $* * *$ & & $36 \cdot 1$ & $* * *$ & 12.8 \\
\hline
\end{tabular}


TABLE 6. - Results of Kruskal-Wallis ANOVA and Mann-Whitney U Test corrected for multiple comparison for tail aspect ratio $\left(A_{\mathrm{R}}\right)$, hepatosomatic index $\left(H_{\mathrm{T}}\right)$, body size-standardised caudal area $\left(A^{\prime}\right)$, span $\left(S^{\prime}\right)$ and muscular-skeletal amount per unit length $\left(E_{\mathrm{M}}{ }^{\prime}\right)$ among Galeus melastomus ( $g$ ), Sciliorhinus canicula ( $s)$, Mustelus asterias $(m)$, Heptranchias perlo $(h)$, Squalus blainvillei (sb; sbf: females; sbm: males), Dalatias licha $(d)$ and Centrophorus uyato $(c)$. In the Bonferroni multiple comparison the underlined species are not significantly different $(P>0 \cdot 00178)$.

\begin{tabular}{|c|c|c|c|c|c|c|c|c|c|c|c|}
\hline \multirow{2}{*}{$\begin{array}{l}\text { Variable } \\
A_{\mathrm{R}}\end{array}$} & \multicolumn{2}{|c|}{$\begin{array}{c}\text { Kruskal-Wallis ANOVA } \\
\text { d.f. } \quad \text { p-level a }\end{array}$} & \multicolumn{8}{|c|}{$\begin{array}{l}\text { Mann-Whitney U Test } \\
\text { Bonferroni multiple comparison }\end{array}$} & \multirow{2}{*}{$\frac{\text { p-level }^{\mathrm{b}}}{*}$} \\
\hline & $7 ; 379$ & $* * *$ & $g$ & $s$ & $m$ & $h$ & $s b f$ & $s b m$ & $d$ & $c$ & \\
\hline$H_{\mathrm{I}}$ & $7 ; 318$ & $* * *$ & $g$ & $s$ & $m$ & $h$ & $s b m$ & $s b f$ & $d$ & $c$ & * \\
\hline$A^{\prime}$ & $7 ; 379$ & $* * *$ & $m$ & $s$ & $s b m$ & $s b f$ & $c$ & $d$ & $h$ & $g$ & $*$ \\
\hline$S^{\prime}$ & $7 ; 379$ & $* * *$ & $s$ & $g$ & $m$ & $h$ & $s b m$ & $s b f$ & $c$ & $d$ & $* *$ \\
\hline$E_{M}$ & $7 ; 379$ & $* * *$ & $g$ & $s$ & $m$ & $s b$ & $h$ & $d$ & $c$ & & $*$ \\
\hline
\end{tabular}

$\mathrm{a}^{*} \mathrm{p}<0.00178$; b Only the lowest significance level (after Bonferroni's correction) is reported: ** $\mathrm{p}<0.00035^{* * *} \mathrm{p}<0.001$
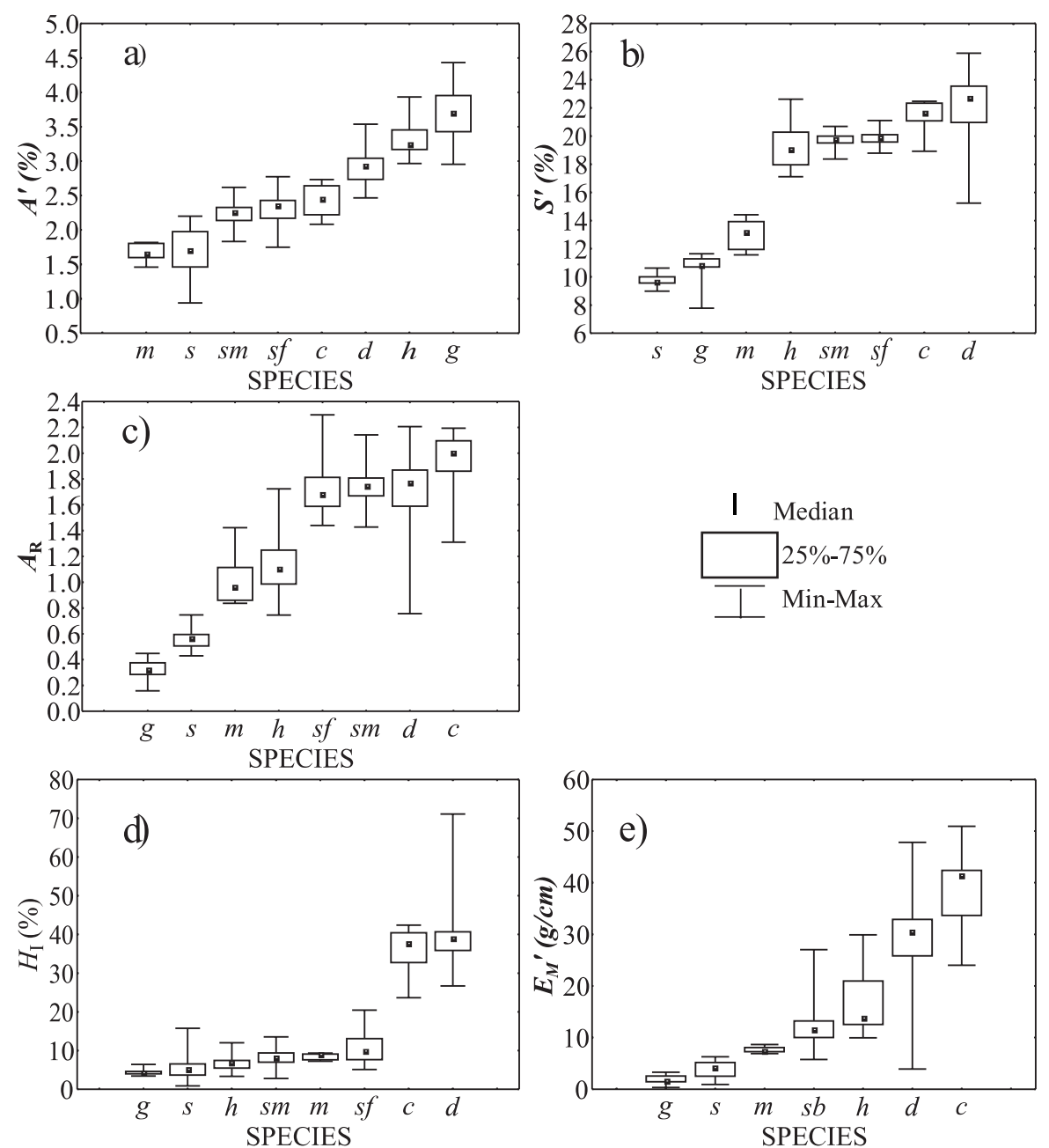

FIG. 5. - Box-plots showing median values (empty squares), first and third quartiles (empty rectangles) and minimum-maximum values (error bars) for body size-standardised caudal fin area $\left(A^{\prime}\right.$, plot a), body size-standardised caudal fin span ( $S^{\prime}$, plot b), caudal fin aspect ratio $\left(A_{\mathrm{R}}\right.$, plot c), hepatosomatic index $\left(H_{\mathrm{F}}\right.$, plot d) and muscular-skeletal amount per unit length $\left(E_{\mathrm{M}}\right.$ ', plot e) in Galeus melastomus $(g)$, Scyliorhinus canicula $(s)$, Heptranchias perlo (h), Squalus blainvillei (sbm: males; sbf: females), Mustelus asterias (m), Centrophorus uyato (c) and Dalatias licha $(d)$. In each plot, species are ranked according to increasing order of the median values. 


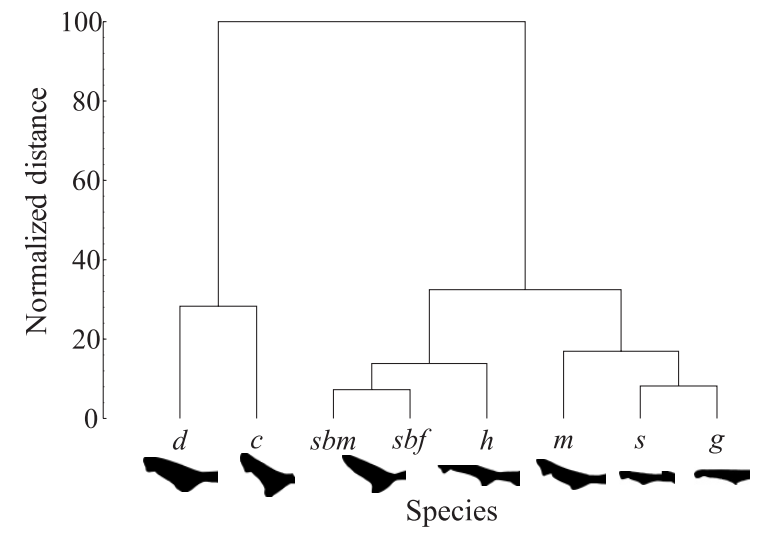

FIG. 6. - Dendrogram of the seven investigated demersal sharks using UPGMA clustering from Euclidean distances based on median values per species of body size-standardised caudal fin span and area, tail aspect ratio, hepatosomatic index and muscular-skeletal amount per unit length for Galeus melastomus ( $g$ ), Scyliorhinus canicula $(s)$, Heptranchias perlo (h), Squalus blainvillei (sbm: males; sbf: females), Mustelus asterias $(m)$, Centrophorus uyato $(c)$ and Dalatias licha $(d)$. The normalised distance is (linkage distance)/ (maximum distance)*100. The schematic representation of the species' caudal shapes is also reported.

As shown by the cluster analysis (Fig. 6), the species studied were grouped into two main clusters: one composed by $d$ and $c$ well separated from the other cluster which, in turn, was split into two subclusters ( $s b m, s b f$ and $h$ in the first one, and $g, s$ and $m$ in the second one). Similarity between $d$ and $c$ was less than among $g, s$ and $m$ and even more when compared to the group composed by $s b m, s b f$ and $h$, which showed the highest similarity.

The PCA ordinated fish points along two main components, $\mathrm{PC} 1$ and $\mathrm{PC} 2$, which explained $61.69 \%$ and $27.45 \%$ of the total variance respectively (Table 7). The fish coordinates decreased along PC1 from $g$ to $d$ and $c$, whereas the coordinates increased along PC2 from $g$ to $s$ (Fig. 7). The active variables $E_{\mathrm{M}}{ }^{\prime}, S^{\prime}$ and $H_{\mathrm{I}}$ were correlated more to $\mathrm{PC} 1$ than PC2, and exhibited similar contributions to the former component (Table 7); conversely, $A^{\prime}$ was strongly correlated with PC2 (Fig. 7), since the contribution of this latter vari-

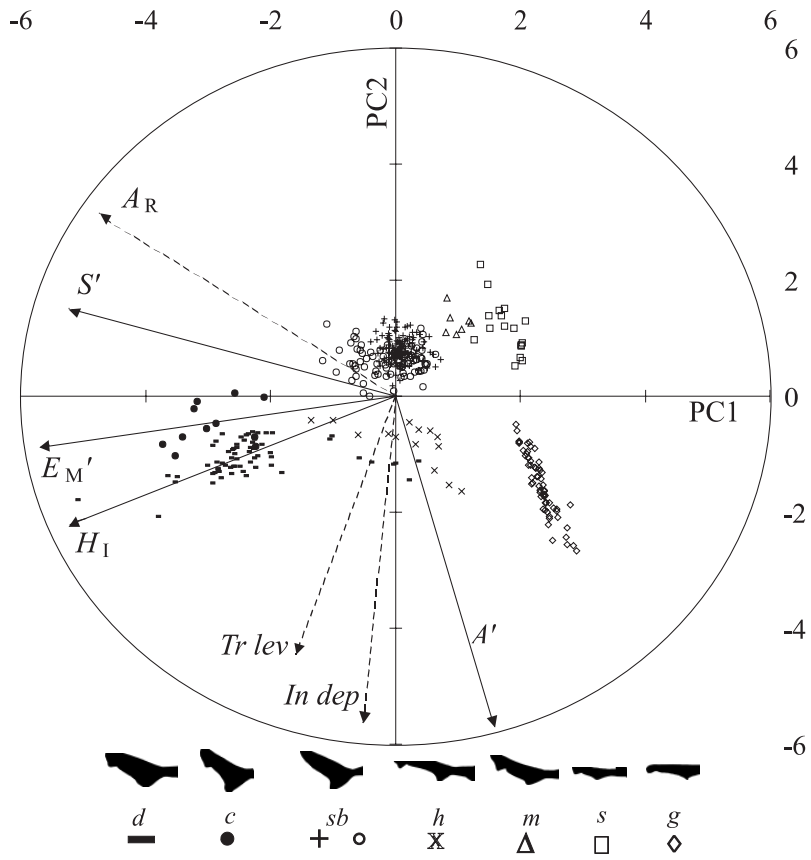

FIG. 7. - PCA-biplot representing cases (G. melastomus: $g$, open diamonds, $S$. canicula: $s$, open squares, M. asterias: $m$, open triangles, $C$. uyato: $c$, filled circles, D. licha: $d$, horizontal bars, S. blainvillei: $s b$; females: open circles, males: plus and $H$. perlo: $h$, crosses) active ( $S^{\prime}$ : body size-standardised caudal span, $A^{\prime}$ : body size-standardised caudal area, $E_{\mathrm{M}}$ ': muscular-skeletal amount per unit length and $H_{\mathrm{I}}$ : hepatosomatic index $)$ and supplementary $\left(A_{\mathrm{R}}\right.$ caudal fin aspect ratio, Tr lev trophic level and In dep depth inhabited) variables projected on the principal component-plane (PC1*PC2). Solid and dashed vectors represent active and supplementary variable correlations respectively, with horizontal (PC1) and vertical (PC2) components from PCA. The schematic representation of the species' caudal shapes is also reported.

able was the highest compared to the other variables (Table 7). The supplementary variables $\mathrm{Tr} l e v$ and $I n$ dep had higher correlations with PC2 compared with PC1 (Fig. 7), whereas $A_{\mathrm{R}}$ was correlated more with PC1 than PC2 (Table 7). The fish coordinates along PC1 were significantly correlated with values of $A_{\mathrm{R}}$ $\left(\mathrm{PC} 1=2.96-2.08^{*} A_{\mathrm{R}} ; \mathrm{F}\right.$ test, d.f. 1 and $377, R^{2}=0 \cdot 60$, $P<0.001)$. The results from the multiple regression analysis (Multiple regression, whole model: $\mathrm{F}$ test, d.f. 2 and $\left.4, R^{2}=0 \cdot 87, P<0 \cdot 01\right)$ indicate median In dep

TABLE 7. - PCA component statistics, active ( $E_{\mathrm{M}}{ }^{\prime}$ : muscular-skeletal amount per unit length, $S^{\prime}$ : body size-standardised caudal fin span, $H_{\mathrm{I}}$ : hepatosomatic index and $A^{\prime}$ : body size-standardised caudal fin area) and supplementary $\left(A_{\mathrm{R}}\right.$ : caudal fin aspect ratio, $\operatorname{Tr}$ lev: trophic level and In dep: depth inhabited) variable correlations ( $\mathrm{r}$ ) with principal components (PC1, PC2) and active variable relative contributions (r \%) to data ordination in the PCA analysis. The components used for data ordination are in bold and the supplementary variables are underlined.

\begin{tabular}{|c|c|c|c|c|c|c|c|c|c|c|c|c|c|c|c|}
\hline \multirow[t]{2}{*}{ Components } & \multirow[t]{2}{*}{ Eigenvalue } & \multirow{2}{*}{$\begin{array}{l}\text { Total } \\
(\%)\end{array}$} & \multirow[t]{2}{*}{ Cumulative } & \multirow{2}{*}{$\begin{array}{c}\text { Cumulative } \\
(\%)\end{array}$} & \multirow{2}{*}{\multicolumn{2}{|c|}{$E_{\mathrm{M}}^{\prime}{ }_{\mathrm{r} \%}^{\prime}$}} & \multicolumn{2}{|c|}{$S^{\prime}$} & \multicolumn{2}{|c|}{$H_{\mathrm{I}}$} & \multicolumn{2}{|c|}{$A^{\prime}$} & \multirow{2}{*}{$\underset{\mathrm{r}}{\underline{A_{\mathrm{R}}}}$} & \multirow{2}{*}{$\frac{\text { Trlev }}{r}$} & \multirow{2}{*}{$\frac{\operatorname{Indep}}{\mathrm{r}}$} \\
\hline & & & & & & & $\mathrm{r}$ & $\mathrm{r} \%$ & $\mathrm{r}$ & $\mathrm{r} \%$ & $\mathrm{r}$ & $\mathrm{r} \%$ & & & \\
\hline PC1 & $2 \cdot 47$ & $61 \cdot 69$ & $2 \cdot 47$ & $61 \cdot 69$ & -0.95 & $0 \cdot 36$ & $-0 \cdot 86$ & 0.30 & $-0 \cdot 87$ & $0 \cdot 31$ & $0 \cdot 26$ & 0.03 & $-0 \cdot 77$ & $-0 \cdot 27$ & $-0 \cdot 08$ \\
\hline PC2 & $1 \cdot 10$ & $27 \cdot 45$ & $3 \cdot 57$ & $89 \cdot 13$ & $-0 \cdot 15$ & 0.02 & 0.25 & 0.06 & $-0 \cdot 37$ & $0 \cdot 12$ & -0.94 & $0 \cdot 80$ & 051 & $-0 \cdot 74$ & -0.92 \\
\hline PC3 & $0 \cdot 31$ & $7 \cdot 82$ & $3 \cdot 88$ & $96 \cdot 96$ & - & - & - & - & - & - & - & - & - & - & - \\
\hline PC4 & $0 \cdot 12$ & 3.04 & $4 \cdot 00$ & $100 \cdot 00$ & - & - & - & - & - & - & - & - & - & - & - \\
\hline
\end{tabular}


as a better predictor of the median of PC2 fish coordinates (Multiple regression, predictor contribution: $\mathrm{t}$ $\left.{ }_{4}=-4 \cdot 16, \beta=-1 \cdot 27 \pm 0 \cdot 30, \mathrm{~B}=-6^{*} 10^{-3} \pm 10^{-3}, P<0 \cdot 05\right)$ compared to mean Tr lev of the studied species (Multiple regression, predictor contribution: $\mathrm{t}_{4}=1 \cdot 24, \beta=$ $0 \cdot 38 \pm 0 \cdot 31, \mathrm{~B}=1 \cdot 43 \pm 1 \cdot 15, P=0 \cdot 28)$. The correlation matrix of the mean Tr lev, median In dep and median $A$ ' showed In dep to be significantly correlated both with $A^{\prime}(\mathrm{r}=0.82, \mathrm{n}=7, P<0.05)$ and Tr lev $(\mathrm{r}=0 \cdot 88, \mathrm{n}=7$, $P<0 \cdot 01)$ of the species studied.

\section{DISCUSSION}

The following considerations were not inferred from direct kinematic observations of the species' swimming behaviours, but were based on the general implications of the morphometrics studied for shark swimming. Therefore, the morpho-functional implications that are discussed have a putative connotation.

\section{Size and sex-related variation}

The positive size-related effect on caudal fin morphometrics observed in the catsharks and squaloids, S. blainvillei and D. licha, may be explained according to the interpretation previously provided of an ontogenic effect in thunnids and euthynnids (Magnuson, 1978). In fact, a size-related increase in these morphometrics can also be advantageous for counteracting the increasing drag per unit length experienced by larger sharks. These results were in contrast with data on the great white shark, Carcharodon carcharias (Lingham-Soliar, 2004a), which exhibits a negative caudal fin allometry at a larger size, probably in relation to a lower lift/drag ratio compared to smaller individuals.

However, this size-related effect varied depending on the species studied. The results on caudal span and aspect ratio confirmed observations that squaloids are more efficient swimmers than catsharks (Thomson, 1976; Thomson and Simanek, 1977), considering that a higher caudal aspect ratio and span generally relate to a better ability for sustained swimming speed (Webb, 1978; Lingham-Soliar, 2004a) and to a higher tail beat frequency (Webb and Keyes 1982) respectively. However, differences in size related variation of the caudal area may have to be imputed to different factors, such as the depth inhabited and/or trophic levels (see below).
The size-related increase in the hepatosomatic index observed in the studied squaloids suggests that the increasing size-related effect of passive buoyancy (Bone and Roberts, 1969; Baldridge, 1970, 1972) could translate into a more pelagic niche for bigger individuals. Alternatively, such an increase could facilitate slow swimming while minimising the energy needed to prevent sinking, as suggested by Lingham-Soliar (2004a) for the great white shark. The ontogeny of the swimming behaviour could be also sex-related in S. blainvillei, as larger females are more suited to a pelagic habit and are slower swimmers compared to larger males (which exhibited lower size-standardised caudal span and area as median values). These clues let us hypothesise a size and/or sex related swimming behaviour for these species. Similar squaloids, such as Squalus achantias Linnaeus, 1758 and Squalus megalops (Macleay, 1881), show a sex and sizestructured schooling behaviour (Compagno, 1984; Last and Stevens, 1994). The known schooling behaviour of D. licha and S. blainvillei (Last and Stevens, 1994; Froese and Pauli, 2007) could be related to sex and size.

However, the low hepatosomatic index observed in the two catsharks was not size-related, as previously observed in the catshark Holohalaerus regani (Gilchrist, 1922) (Richardson et. al., 2000), which suggests a strictly benthic niche that does not take advantage of a size-related increase in passive buoyancy. Finally, the length-weight relationships showed positive allometry in all species, and the variation rates of these relationships were similar.

Data on size and/or sex-related variation suggests that the ontogeny of the analysed variables is strongly species-specific. This may indicate speciesspecific amounts of phenotypic plasticity (Domenici et al., 2007; Higham, 2007) in response to the effect of changing hydrological conditions and/or ecological demands (i.e. increasing drag per unit length experienced by larger fish, different aptitudes for swimming, pelagic shift in habitat of adult individuals, different depths inhabited and/or trophic level). Recently, phenotypic plasticity was demonstrated at the intra-specific level for changes in caudal morphometry in response to hydrological conditions in some fresh (Imre et al., 2002) and marine water (Marcil et al., 2006) bony fish. Lingham-Soliar (2004a, 2005) studied the implications of caudal fin allometry for locomotory performance and ecology in the white shark. 


\section{Interpretation of multivariate results: horizontal gradient}

As demonstrated by the $\mathrm{PC} 1-A_{\mathrm{R}}$ relationship, a gradient of swimming ability may be observed between a low tail aspect ratio in catsharks and a relatively higher one in the squaloids $D$. licha and C. uyato (relating to an aptitude for a very low and a relatively high sustained speed respectively; Webb, 1978). Given the PCA results, such different swimming abilities can be related to different values of proportional caudal span (related to different aptitudes for steady swimming; Webb 1978; Lingham-Soliar, 2004a), hepatosomatic index (related to different conditions of passive buoyancy; Bone and Roberts, 1969; Baldridge, 1970, 1972; Lingham-Soliar, 2004a) and muscular-skeletal amount per unit length (related to different productions of swim power; Donley and Shadwick, 2003). These morpho-functional implications for shark swimming were taken into consideration to explain patterns of variations among the studied species; therefore, relative bibliographic citations have not been repeated further.

The limited ability of the catsharks for sustained swimming can be related to a low tail beat frequency, low passive buoyancy and a limited production of swim power. These characteristics suggest a slow manoeuvring, unsteady swimming mode for the two species. This similarity between the catsharks, which was supported by the cluster analysis results, matched the morphological classification of Thomson and Simanek (1977).

Given the intermediate values of their tail aspect ratio, both $M$. asterias and $H$. perlo might be more able to produce sustained speed compared to the catsharks. This ability could be linked both to a moderate effect of passive buoyancy and a moderate tail beating frequency. However, the larger amount of muscular mass per unit length of $H$. perlo with respect to $M$. asterias might enhance the production of swim power in the former species, which is reported to be a very active swimmer in a wide bathymetrical range (Froese and Pauly 2007; Last and Stevens, 1994; Compagno and Niem, 1998 b). As suggested by the cluster analysis results, it is likely that these two species cover an intermediate position between strictly benthic and more demersal sharks: $M$. asterias is more similar to the catsharks than to $H$. perlo, which in turn is closer to the squaloid S. blainvillei. This pattern partially agrees with the classification by Thomson and Simanek (1977), in which both species are included in the same morphological group of catsharks.

As shown by the $\mathrm{PC} 1-A_{\mathrm{R}}$ relationship, $C$. uyato and $D$. licha have higher tail aspect ratios and a general similarity of their caudal fin shape compared to $S$. blainvillei. However, the resulting differences were mainly related to a conspicuous proportion of liver mass over body mass and to a high muscularskeletal amount per unit length, which characterised C. uyato and D. licha. These data suggest that the latter species could benefit from both high passive buoyancy and powerful swim production. These characteristics matched the observations of other authors (Macpherson, 1979; Compagno, 1984; Macpherson and Roel, 1987; Compagno et al., 1989; Cortés, 1999), who described these species as very active feeders within the water column, efficiently moving from the bottom to the water column and vice versa. Furthermore, D. licha and C. uyato may be able to reduce tail drag more efficiently than $S$. blainvillei, given that a higher proportional caudal span relates to more ability in steady swimming with a higher tail beat frequency.

The differences observed among the studied squaloids were also confirmed by the cluster analysis results, which separated $S$. blainvillei from $D$. licha and $C$. uyato and assimilated it to $H$. perlo. This result was partially in agreement with the morphological classification of Thomson and Simanek (1977), who put all these species together in a separate group (group four), which contained only squaloid species. S. blainvillei exhibited mixed features between $H$. perlo, D. licha and C. uyato. Like D. licha and $C$. uyato it had a relatively high tail aspect ratio (relating to an aptitude for a relatively high sustained speed) and like $H$. perlo it had intermediate values for the hepatosomatic index, caudal fin span and muscular-skeletal amount per unit length, which reflect buoyancy condition, tail beat frequency and potential swim power production respectively.

\section{Interpretation of multivariate results: vertical gradient}

In the PCA analysis, proportional caudal area contributed most to species separation along PC2, which was confirmed by parametric and non-parametric univariate analyses. A direct proportionality between the production of thrust and the amplitude of caudal area was observed both in steady swimmers, such as scombroids (Magnuson, 1978), and 
unsteady swimmers, such as non-scombroid bony fishes (Webb, 1978) and sharks (Webb and Keyes, 1982). Therefore, it can be expected that the observed differences in the proportion of caudal area over body size could reflect different abilities in thrust production among the studied species, which were all to different extents unsteady swimmers (Thomson and Simanek, 1977).

It is hypothesised that these different abilities could be linked to two main aspects:

Since the fish functional design plays an important role in swimming performance (Blake, 2004), an increase in the proportion of the caudal area can increase the burst swimming ability (Webb and Keyes, 1982), and thus influence feeding habits (Higham 2007). It can be expected that a higher proportion of the caudal area may be advantageous for hunting fast nektonic organisms, whereas a lower one limits feeding to slower prey (i.e. benthic). More ability to feed on fast nektonic prey could lead to a higher trophic level in the food chain because a higher trophic level represents a higher number of energy transfer steps to that level (Odum and Heald, 1975). As a result, more efficient burst swimmers (i.e. larger caudal area sharks) are expected to occupy higher trophic levels compared to less efficient burst swimmers (i.e. smaller caudal area sharks). Consequently, a direct relationship between caudal area and trophic level can then be hypothesised for the studied species, also taking into consideration the interrelationships between energy balance, swimming and caudal morphometry which were demonstrated for several fish species (Pauly, 1986; Sambilay, 1990).

Although all the studied sharks were to different extents opportunistic feeders (trophic level 2.8 and up; Cortes, 1999), literature data (see results) indicates some differences in their food preferences and hence in their trophic levels. Species (G. melastomus, H. perlo, D. licha and C. uyato) that include faster prey in their diet have both high trophic levels (4.0 and up) and large-intermediate caudal areas, while species (M. asterias, S. canicula and S. blainvillei) with small-intermediate caudal areas prefer benthic and bentho-demersal prey and have trophic levels less than 4.0. Moreover, this pattern could also be supported by the different grades of phenotypic plasticity found for the caudal area between the two groups of species.

An increase in the proportion of caudal area could be related to an increase in the depth inhabited by the species. It can be expected that deep-water sharks ( $G$. melastomus, H. perlo, C. uyato and D. licha), due to the higher density of deep-water masses (Newton, 1999), must counteract a higher drag while swimming than shape-comparable shallower species (M. asterias, $S$. canicula and S. blainvillei). Therefore, a larger caudal area might be an adaptation to counteract higher drag for the deep-water sharks studied. The general relation describing the drag against the body movement through a fluid (drag $=1 / 2^{*} C^{*} A^{*} V^{2 *} \rho$ where $C$ is the constant depending on the body shape, $A$ the area of the perpendicular section against the movement, $V^{2}$ the squared velocity of the moving body and $\rho$ the fluid density; Lindsey, 1978) showed that drag is positively related to morphology, squared velocity of the moving body and fluid density. Assuming that the studied species were under the same kinematic conditions, they might only experience drag as a function of body morphology and seawater density. The sea water density $(\rho)$ increases with depth as a complex function of salinity, pressure and temperature $(\rho=f$ $(S, T, P))$ (Newton, 1999). Depth-density profiles of the Mediterranean basins can vary locally, but generally water density increases with depth (Pinardi and Masetti, 2000). For instance, in the study area (Strait of Sicily, southern central Mediterranean), the standard density $\rho_{0}\left(\rho_{0}=\rho^{*}(1-1000)\right)$ shows an increment of circa $12 \%$ between the surface and an approximate depth of $250 \mathrm{~m}$ (D'Ortensio et al., 2005), and remains fairly constant below this point thanks to the particular water circulation of the Mediterranean Sea (Cognetti and Sarà, 1974; Ghirardelli, 1981). This increase in seawater density between the surface and deep waters could represent an auto-ecological selection force (Alberch et al., 1979) that determines morphological adaptations (Higham, 2007) for shark swimming. Elasmobranchs are mainly unsteady swimmers (Webb, 1978), and enhance the thrust needed for swimming mostly with a larger caudal area (Magnuson, 1978; Webb and Keys, 1982), as sharks are unable to significantly modify fin depth and area (Webb, 1978; Webb and Keys, 1982). Sharks (G. melastomus, $H$. perlo, D. licha and C. uyato) that have larger to intermediate proportional caudal areas are deep-water species (Fischer et al., 1987; Notarbartolo di Sciara and Bianchi, 1998; Serena, 2005). This pattern is also supported by the higher size-related increase in caudal area observed in deep-water species (D. licha and $G$. melastomus) compared to the shallow water species (S. blainvillei and especially $S$. canicula). A further indication of the effect of the depth inhabited can be found in the differences observed in the tail aspect ra- 
tios of catsharks: although they share the benthic habitat, the coastal $S$. canicula exhibited a higher tail aspect ratio compared to the deep-water G. melastomus. This could indicate an adaptation to deep-waters for the latter species since it was observed that for benthic swimmers, a low tail aspect ratio is an adaptation to environments with a low Reynolds number (a condition found in more viscous fluids, like those found at greater depths) (Aleev, 1963).

These data suggest that deep-water species produce a more powerful thrust than species living in shallower waters.

Given the results obtained from the multiple regression analysis and correlation matrix, the present data provide more support for the second hypothesis than the first, and suggest a relationship between the depth inhabited and trophic level.

In summary, the data suggest that, (1) the depth inhabited (through sea water density) could be interpreted as a primary selective auto-ecological factor that influences caudal morphometry (i.e. larger area for deep water sharks); (2) the higher trophic level displayed by deep-water sharks could represent either a secondary advantageous outcome of this depth-related effect on caudal area or an independent adaptation to prey availability in a deep environment. Deep waters, unlike shallow waters, usually do not have primary producers (Newton, 1999), and mainly host carnivorous species of trophic level 3 and up (Stergiou and Karpouzi, 2002). Therefore, the higher trophic level observed in deep-water sharks could be a consequence of them feeding on higher trophic level prey, even with the opportunistic feeding behaviour usual for sharks (Cortes, 1999).

Although the regulatory responses that aquatic organisms can implement are very intricate, environmental factors (i.e. depth) can restrict locomotion (i.e. proportional caudal area) and predator-prey interactions (i.e. trophic level) in aquatic organisms (Domenici et al., 2007). As a result, feeding and locomotion can be considered as coevolved activities for aquatic vertebrates, as illustrated by Higham (2007) who studied the interrelationships between pectoral fin area, feeding and locomotion in bony fish.

\section{CONCLUSIONS}

Even if based on a reliable comparison (bodysize standardised data and assumed similar kinematic conditions), the present results are not based on direct kinematic observations and hence do not conclusively solve the interrelationships between depth, trophic habit and swimming behaviour for the studied species. In fact, shark species-specific body morphometry and kinematics might exert basic effects on shark swimming (Wilga and Lauder, 2004b) and on predator-prey interaction (Higham 2007). On the other hand, obtaining a reliable inter-specific comparison based on a kinematic dataset deals with some problems, such as difficulties in collecting data in species' natural environment (Kawabe et al., 2004). Direct and comparative kinematic studies, carried out in natural or simulated natural environments, will conclusively determine both the swimming behaviour and the depth and/or trophic-related effects on caudal area hypothesised for the present shark assemblage.

Nevertheless, this study, which examines caudal morphometrics, the hepatosomatic index and muscular-skeletal amount per unit length in seven selected demersal sharks, provided for the first time a quantitative and comparative dataset for these species as a group. Furthermore, an attempt was made at attributing the observed variation patterns to the expected swimming diversity and niche (depth and/or trophic habit). These clues may be useful for further research aimed at evaluating the interrelationships between body shape, swimming modes and environment in demersal sharks.

\section{ACKNOWLEDGEMENTS}

We would like to thank Barbara Catalano and Massimiliano Bottaro for their logistic support and help. We are grateful to Enrico Gennari, Edoardo Mostarda and Angela Sarni for many constructive comments and help, which greatly improved the manuscript. We would also like to thank the anonymous referees who reviewed the manuscript.

\section{REFERENCES}

Alberch, P., S.J. Gould, G.F. Oster and D.B. Wake. - 1979. Size and shape in ontogeny and phylogeny. Paleobiology, 5(3): 296-317.

Aleev, Y.G. - 1963. Function and gross morphology in fish. Israel: Program for Scientific Translation.

Alexander, R.M. - 1965. The lift produced by the heterocercal tails of Selachii. J. Exp. Biol., 43: 131-138.

Alexander, R.M. -1967. Functional design in fishes. London: Hutchinson University Library.

Alexander, R.M. - 1968. Animal Mechanics. London: Sidgwick and Jackson.

Baldridge, H.D. Jr - 1970. Sinking factors and average densities of 
Florida sharks as function of liver buoyancy. Copeia, 4: 744-754.

Baldridge, H.D. Jr - 1972. Accumulation and function of liver oil in Florida sharks. Copeia, 2: 306-325.

Belluscio, A., U. Scacco, F. Colloca, P. Carpentieri and G.D. Ardizzone. - 2000. Feeding strategies of two species of demersal chondrichthyans, Galeus melastomus (Rafinesque, 1810) and Etmopterus spinax (Linnaeus, 1758), in the Central Tyrrhenian Sea. Biol. Mar. Medit., 7: 417-426.

Bertrand, J., L. Gil De Sola, C. Papaconstantinou, G. Relini and A. Souplet. - 2000. Contribution on the distribution of elasmobranchs in the Mediterranean Sea (from the MEDITS surveys). Biol. Mar. Medit., 7(1): 385-399.

Blake, R.W. - 2004. Fish functional design and swimming performance. J. Fish Biol., 65: 1193-1222. doi: 10.1111/j.10958649.2004.00568.x

Bone, Q. and B.L Roberts. - 1969. The density of elasmobranches. J. Mar. Biol. Ass. UK, 49: 913-937.

Breder, C.M. - 1926. The locomotion of fishes. Zoologica, 4: 159-297.

Budker, P. - 1971. The life of sharks. Columbia University Press, New York.

Carrassón, M., C. Stefanescu and J.E. Cartes. - 1992. Diets and bathymetric distributions of two bathyal sharks of the Catalan deep sea (western Mediterranean). Mar. Ecol. Progr. Ser., 82: 21-30

Clarke, K.R. and R.M. Warwick. - 2001. Change in marine communities: an approach to statistical analysis and interpretation, 2nd edn. PRIMER-E, Plymouth.

Clarke, M.W., P.L. Connolly and J.J. Braken. - 2001. Aspects of reproduction of the deep water sharks Centroscymnus coelolepis and Centrophorus squamosus from west of Ireland and Scotland. J. Mar. Biol. Ass. UK, 81: 1019-1029.

Cliff, G., S.F.J. Dudley and B. Davis. - 1989. Sharks caught in the protective gill nets off Natal, South Africa. 2. The great white shark Carcharodon carcharias (Linnaeus). S. Afr. J. Mar. Sci., 8: 131-144.

Cognetti, G. and M. Sará. - 1974. Biologia Marina. Calderini, Bologna.

Compagno, L.J.V. - 1984. FAO species catalogue. Vol. 4. Sharks of the world. An annotated and illustrated catalogue of shark species known to date. Part 1. Hexanchiformes to Lamniformes. FAO Fisheries Synopsis. (125, Vol. 4, Part 1), 249 pp.

Compagno, L.J.V., D.A. Ebert and M.J. Smale. - 1989. Guide to the sharks and rays of southern Africa. NEM Holland (Publ.) Ltd, London.

Compagno, L.J.V. and V.H. Niem. - 1998 b. Hexanchidae. Cowsharks, sixgill, and seven gill sharks. In: K.E. Carpenter and V.H. Niem (eds.), FAO Identification Guide for Fisheries Purposes. The Living Marine Resources of the Western Central Pacific, pp. 1208-1210. FAO, Rome.

Compagno, L.J.V. - 2002. Sharks. Key to families occurring in the area. In: K.E.Carpenter (ed.), FAO species identification guide for fishery purposes. The living marine resources of the Western Central Atlantic: Introduction, molluscs, crustaceans, hagfishes, sharks, batoid fishes, and chimaeras, Vol. 1, pp. 363505. FAO, Rome.

Corner, E.D.S., F.R.S. Denton and G.R. Forster. - 1969. On the buoyancy of some deep sea sharks. Proc. Roy. Soc. B-Biol., 171: 415-429.

Cortès, E. - 1999. Standardized diet compositions and trophic levels of shark. ICES J. Mar. Sci., 56: 707-717.

Craik, J.C.A. - 1978. An annual cycle of vitellogenesis in the elasmobranch Scyliorhinus canicula. J. Mar. Biol. Ass. UK, 58: 719-726.

D’Ortensio, F., D. Iudicone, C. de Boyer Montegut, P. Testor, D. Antoine, S. Marullo, R. Santoleri and G. Madec.- 2005. Seasonal variability of the mixed layer depth in the Mediterranean Sea as derived from in situ profiles. Geophys. Res. Lett., 32: L12605. doi:10.1029/2005GL022463

Domenici, P., G. Claireaux and D.J. McKenzie. - 2007. Environmental constraints upon locomotion and predator-prey interactions in aquatic organisms: an introduction. Philos. Trans. Roy. Soc. B, 362: 1929-1936. doi:10.1098/rstb.2007.2078

Donley, J. and R. Shadwick.- 2003. Steady swimming muscle dynamics in the leopard shark Triakis semifasciata. J. Exp. Biol., 206: 1117-1126.

Ellis, J.R., M.G. Pawson, and S.E. Shackley. - 1996. The compara- tive feeding ecology of six species of shark and four species of ray (Elasmobranchii) in the north-east Atlantic. J. Mar. Biol. Ass. UK, 76: 89-106.

Ferry, L.A. and G.V. Lauder. - 1996. Heterocercal tail function in leopard sharks: a three-dimensional kinematic analysis of two models. J. Exp. Biol., 199: 2253-2268.

Fischer, W., M.L. Bauchot and M. Schneider. - 1987 Fiches FAO d'identification des espèces pour les besoins de la pêche. Méditerranée et Mer Noire. Zones de pêche 37 Vertébrés. Vol. 2. FAO, Rome.

Fish, F.E. and L.D. Shannahan. - 2000. The role of the pectoral fins in body trim of sharks. J. Fish Biol., 56: 1062-1073.

Froese, R. and D. Pauly. - 2007. FishBase. World Wide Web electronic publication. www.fishbase.org, version (11/2007).

Gabriel, K.R. - 1971. The biplot graphic display of matrices with application to principal component analysis. Biometrika, 58(3): 453-467.

Gabriel, K.R. - 1982. Biplot. In: S. Kotz and N.L. Johnson (eds.), Encyclopedia of Statistical Sciences, vol. 1, pp. 263-271, Wiley, New York.

Gabriel, K.R. and C.L. Odoroff. - 1990. Biplots in biomedical research. Stat Med., 9(5): 469-485.

Ghirardelli, E. - 1981. La vita nelle acque. Utet, Torino

Gibson, R.N. and I.A. Ezzi. - 1987. Feeding relationships of a demersal fish assemblage on the west coast of Scotland. J. Fish. Biol., 31: 55-69.

Gould, S.J. and N. Eldredge. - 1977. Punctuated equilibria: the tempo and mode of evolution reconsidered. Paleobiology, 3: $115-151$.

Gower, J.C. and D.J. Hand. - 1996. Biplots. Chapman and Hall, London.

Graffelman, J. and T. Aluja-Banet. - 2003. Optimal representation of supplementary variables in biplots from principal component analysis and correspondence analysis. Biometrical J., 45(4): 491-509.

Hennemann, R.M. - 2001. Sharks and rays: Elasmobranch guide of the world. IKAN- Unterwasserarchiv, Frankfurt.

Higham, T.E. - 2007. The integration of locomotion and prey capture in vertebrates: Morphology, behaviour, and performance. Integr. Comp. Biol., 47(1): 82-95. doi:10.1093/icb/icm021

Imre, I., R.L. MCLaughlin and D.L.G. NoAKes. - 2002. Phenotypic plasticity in brook charr: changes in caudal fin induced by water flow. J. Fish Biol., 61(5): 1171-1181. doi:10.1111/j.10958649.2002.tb02463.x

Kawabe, R., Y. Naito, K. Sato, K. Miyashita and N. Yamashita. 2004. Direct measurement of the swimming speed, tailbeat, and body angle of Japanese flounder (Paralichthys olivaceus). ICES J. Mar. Sci., 7: 1080-1087. doi: 10.1016/j.icesjms.2004.07.014

Kohler, N.E., J.G. Casey and P.A. Turner. - 1996. Length-length and length-weight relationships for 13 Shark Species from the Western North Atlantic. NOAA Technical Memorandum NMFS-NE-110, May 1996. http://na.nefsc.noaa.gov/sharks/lw /length. html.

Koob, T.J. and I.P. Callard. - 1999. Reproductive endocrinology of female elasmobranches: lessons from the little skate (Raja erinacea) and spiny dogfish (Squalus acanthias). J. Exp. Zool., 284: $557-574$.

Kramer, E. - 1960. Zur Form und Funktion des Lokomotionsapparates der Fische. Z. Wiss. Zool. ABT A, 163: 1-63.

Krebs, C.J. - 1989. Ecological Methodology. NEM York: Harper and Row.

Last, P.R. and J.D. Stevens. - 1994. Sharks and rays of Australia. Australia: CSIRO.

Lauder, G.V. - 2000. Function of the caudal fin during locomotion in fishes: kinematics, flow visualization, and evolutionary patterns. Am. Zool., 40: 101-122.

Lighthill, M.J. - 1970. Aquatic animal propulsion of high hydromechanical efficiency. J. Fluid Mech., 44: 265-301.

Lindsey, C.C. - 1978. Form, function and locomotory habits in fish. In: W.S. Hoar and D.J. Randall (eds.), Fish Physiology, vol. 7, pp. 1-100. Academic Press, London.

Lingham-Soliar, T. - 2004a. Caudal fin allometry in the white shark Carcharodon carcharias: implications for locomotory performance and ecology. Naturwissenschaften, 92: 231-236.

Lingham-Soliar, T. - 2004b. Dorsal Fin in the White Shark, Carcharodon carcharias: A Dynamic Stabilizer for Fast Swimming. $J$. Morph., 260: 1-11. 
Lingham-Soliar, T. - 2005. Caudal Fin in the White Shark, Car charodon carcharias: A Dynamic Propeller for Fast, Efficient Swimming. J. Morph., 264: 233-252.

Lingham-Soliar, T. and G. Plodowski. - 2007. Taphonomic evidence for high-speed adapted fin in thunniform ichthyosaurs. Naturwissenschaften, 94: 65-70.

Macpherson, E. - 1979. Relations trophiques des poisons dans la Méditerranée occidentale. Rapp. Comm. Int. Explor. Sci. Mer Méditerr., 25/26: 49-58.

Macpherson, E. and B.A .Roel. - 1987. Trophic relationships in the demersal fish community off Namibia. S. Afr. J. Mar. Sci., 5: 585-596.

Magnuson, J.J. - 1978. Locomotion by scombrid fishes: hydromechanics, morphology and behaviour. In: W.S. Hoar and D.J. Randall (eds.), Fish Physiology, vol. 7, pp. 239-313. Academic Press, London.

Marcil, J., D.P. Swain and J.A. Hutchings. - 2006. Genetic and environmental components of phenotypic variation in body shape among populations of Atlanticcod (Gadus morhua L.). Biol. J. Linn. Soc., 88(3): 351-365. doi:10.1111/j.10958312.2006.00656.x

Massutí, E. and J. Moranta. - 2003. Demersal assemblages and depth distribution of elasmobranches from the continental shelf and slope off the Balearic Islands (western Mediterranean). ICES J. Mar. Sci., 60: 753-766.

Newton, G.M. - 1999. The deep-sea environment - Earth's final frontier. Aust. Mar. Sci. Bull., 147: 17-21.

Notarbartolo Di Sciara, G. and I. Bianchi. - 1998. Guida degli squali e delle razze del Mediterraneo. Franco Muzzio.

Odum, W.E. and E.J. Heald. - 1975. The detritus-based food web of an estuarine mangrove community. In: L.E. Cronin (ed.), Estuarine research, Vol 1, pp. 265-286. Accademic Press, New York.

Olaso, I., F. Velasco, F. Sànchez, A. Serrano, C. Rodrìguez-Cabello and O. Cendrero. - 2004. Trophic relations of lesser-spotted catshark (Scyliorhinus canicula) and blackmouth catshark (Galeus melastomus) in the Cantabrian Sea. J. Northwest Atl. Fish. Soc., 35 upload date: 16 Dec 04. http://journal.nafo.int/35/ olaso/olaso-main.html.

Pauly, D. - 1986. A simple method for estimating the food consumption of fish populations from growth data and food conversion experiments. Fish. Bull., 84(4): 827-840.

Perry, C. and B.D. Roitberg. - 2006. Trophic egg laying: hypotheses and tests. Oikos, 112(3): 706-714. doi: 10.1111/j.00301299.2006.14498.x

Pinardi, N. and E. Masetti. - 2000. Variability of the large scale general circulation of the Mediterranean Sea from observations and modelling: a review. Palaeogeogr. Palaeoclimatol. Palaeoecol., 158: 153-173.

Richardson, A.J., G. Maharaj, L.J.V. Compagno, R.W. Leslie, D.A Ebert and M.J. Gibbons. - 2000. Abundance, distribution, morphometrics, reproduction and diet of the Izak catshark. J. Fish Biol., 56: 552-576. doi: 10.1006/jfbi.1999.1182

Sambilay Jr., V.C. - 1990. Interrelationships between swimming speed, caudal fin aspect ratio and body length of fishes. Fishbyte, 8: 16-20.

Sandoval-Castillo, J., A. Rocha-Olivares, C. Villavicencio-Garayzar and E. Balart. - 2004. Cryptic isolation of Gulf of California shovelnose guitarfish evidenced by mitochondrial DNA. Mar Biol., 145(5): 983-988. doi: 10.1007/s00227-004-1378-7

Serena, F. - 2005. Field identification guide to the sharks and rays of the Mediterranean and Black Sea. FAO, Rome.

Siegel, S. and N.J.Jr. Castellan. - 1992. Statistica non parametrica. Mc Graw Hill, Milano.

Sokal, R.R. and F.J. Rohlf. - 1995. Biometry. Freeman, W.H. and Co, New York.

STATISTICA 6.0 (Electronic Version): StatSoft, Inc. - 2006. Electronic Statistics Textbook. Tulsa, OK: StatSoft. WEB: http: // www. statsoft. com / textbook / stathome. html. (Printed Version): Hill, T., Lewicki, P. 2006). STATISTICS Methods and Applications. StatSoft: Tulsa, OK.

Stergiou, K.I. and V.S. Karpouzi. - 2002. Feeding habits and trophic levels of Mediterranean fish. Rev. Fish Biol. Fisher., 11: 217-254.

Sulikowski, J.A., W.B. III Driggers, T.S. Ford, R.K. Boonstra and J.K. Carlson. - 2007. Reproductive cycle of the black nose shark Carcharhinus acronotus in the Gulf of Mexico. J. Fish. Biol., 70(2): 428-440. doi:10.1111/j.1095-8649.2007.01314.x

Thomson, K.S. - 1976. On the heterocercal tail in sharks. Paleobiology, 2: 19-38.

Thomson, K.S. and D.E. Simanek. - 1977. Body form and locomotion in sharks. Am. Zool., 17: 343-354.

Tortonese, E. - 1956. Fauna d'Italia. Leptocardia, Ciclostomata, Selachii. Calderini, Bologna.

Underwood, A.J. - 1997. Experiments in ecology: their logical design and interpretation using analysis of variance. Cambridge University Press, Cambridge, U.K.

Webb, P.W. - 1978. Hydrodynamics: nonscombroid fish. In: W.S. Hoar and D.J Randall (eds.), Fish Physiology, vol. 7, pp.189237. Academic Press, London.

Webb, P.W. - 1984. Form and function in fish swimming. Sci. Am., 251: $58-68$.

Webb, P.W. and R.S. Keyes. - 1982. Swimming kinematics of sharks. Fish. B.-NOAA, 80: 803-812.

Webb, P.W. and R.W. Blake. - 1985. Swimming. In: M. Hildebrand, D.M. Bramble, K.F. Liem and D.B. Wake (eds), Functional vertebrate Morphology, pp. 111-128. Belknap Press, Harward.

Wilga, C.D. and G.V. Lauder. - 2000. Three-dimensional kinematics and wake structure of the pectoral fins during locomotion in leopard sharks, Triakis semifasciata. J. Exp. Biol., 203: 22612278.

Wilga, C.D. and G.V. Lauder. - 2001. Functional morphology of the pectoral fins in bamboo sharks, Chiloscyllium plagiosum: benthic versus pelagic station holding. J. Morph., 249: 195-209.

Wilga, C.D. and G.V. Lauder. - 2002. Function of the heterocercal tail in sharks: quantitative wake dynamics during steady horizontal swimming and vertical manoeuvring. J. Exp. Biol., 205: 2365-2374.

Wilga, C.D. and G.V. Lauder. - 2004 a. Biomechanics: hydrodynamic function of the shark's tail. Nature, 430: 850.

Wilga, C.D. and G.V. Lauder. - 2004 b. Biomechanics of locomotion in sharks, rays, and chimeras. In M. Hildebrand, D.M Bramble, K.F. Liem and D.B. Wake (eds.), Biology of sharks and their relatives, pp. 139-164. CRC Press: LLC.

Yano, K. - 1995. Reproductive biology of the black dogfish, Centroscyllium fabricii, collected from waters off western Greenland. J. Mar. Biol. Ass. UK, 75: 285-310.

Scient. ed.: C. Cuadras.

Received June 27. 2008. Accepted February 27, 2009.

Published online November 19, 2009. 